\title{
Neuregulins Signaling via a Glial erbB-2-erbB-4 Receptor Complex Contribute to the Neuroendocrine Control of Mammalian Sexual Development
}

\author{
Ying J. Ma, ${ }^{1}$ Diane F. Hill, ${ }^{1}$ Kimberly E. Creswick, ${ }^{1}$ Maria E. Costa, ${ }^{1}$ Anda Cornea, ${ }^{1}$ Mario N. Lioubin, ${ }^{2}$ \\ Gregory D. Plowman, ${ }^{2}$ and Sergio R. Ojeda ${ }^{1}$ \\ 1Division of Neuroscience, Oregon Regional Primate Research Center, Beaverton, Oregon 97006, and 2Sugen, Inc., \\ South San Francisco, California 94080
}

Activation of erbB-1 receptors by glial TGF $\alpha$ has been shown to be a component of the developmental program by which the neuroendocrine brain controls mammalian sexual development. The participation of other members of the erbB family may be required, however, for full signaling capacity. Here, we show that activation of astrocytic erbB-2/erbB-4 receptors plays a significant role in the process by which the hypothalamus controls the advent of mammalian sexual maturation. Hypothalamic astrocytes express both the erbB-2 and erbB-4 genes, but no erbB-3, and respond to neuregulins (NRGs) by releasing prostaglandin $\mathrm{E}_{2}\left(\mathrm{PGE}_{2}\right)$, which acts on neurosecretory neurons to stimulate secretion of luteinizing hormonereleasing hormone $(\mathrm{LHRH})$, the neuropeptide controlling sexual development. The actions of TGF $\alpha$ and NRGs in glia are synergistic and involve recruitment of erbB-2 as a coreceptor, via erbB-1 and erbB-4, respectively. Hypothalamic expression of both erbB-2 and erbB-4 increases first in a gonad-independent manner before the onset of puberty, and then, at the time of puberty, in a sex steroid-dependent manner. Disruption of erbB-2 synthesis in hypothalamic astrocytes by treatment with an antisense oligodeoxynucleotide inhibited the astrocytic response to NRGs and, to a lesser extent, that to TGF $\alpha$ and blocked the erbB-dependent, glia-mediated, stimulation of $\mathrm{LHRH}$ release. Intracerebral administration of the oligodeoxynucleotide to developing animals delayed the initiation of puberty. Thus, activation of the erbB-2-erbB-4 receptor complex appears to be a critical component of the signaling process by which astrocytes facilitate the acquisition of female reproductive capacity in mammals.

Key words: astroglial cells; tyrosine kinase receptors; glial growth factors; female sexual development; hypothalamus; puberty
Mammalian sexual development and adult reproductive function depend on the functional integrity of a group of specialized neurosecretory neurons that produce the neuropeptide luteinizing hormone-releasing hormone (LHRH). LHRH-secreting neurons are located in the basal forebrain and send their axons to the median eminence (ME) of the hypothalamus (Silverman et al., 1994) in which they release their secretory products into the portal vasculature for delivery to the anterior pituitary gland.

The regulation of LHRH secretion is exceedingly complex, because it involves multiple transsynaptic inputs, the modulatory influence of gonadal steroids, and the regulatory participation of astroglial cells (Brann and Mahesh, 1994; Ojeda, 1994; Crowley et al., 1995; Ojeda and Ma, 1995; Terasawa, 1995). Hypothalamic astrocytes are in intimate contact with LHRH neurons, because astrocytic processes appose most of the LHRH cell membrane, particularly along the secretory axons (Witkin et al., 1991; King and Letourneau, 1994; Silverman et al., 1994). Astroglial cells affect LHRH neuronal function by both remodeling the delivery sites of LHRH neurosecretory axons in the median eminence (Witkin et al., 1991; King and Letourneau, 1994) and the pro-

Received June 25, 1999; revised Sept. 2, 1999; accepted Sept. 2, 1999.

This work was supported by National Institutes of Health Grants HD25123, P30 Population Center Grant HD18185, and RR00163 for the operation of the Oregon Regional Primate Research Center.

Correspondence should be addressed to Sergio R. Ojeda, Division of Neuroscience, Oregon Regional Primate Research Center, 505 N.W. 185th Avenue, Beaverton, OR 97006. E-mail: ojedas@ohsu.edu.

Copyright (C) 1999 Society for Neuroscience 0270-6474/99/199913-15\$05.00/0 duction of trophic (Melcangi et al., 1995; Tsai et al., 1995; Voigt et al., 1996) and neuroactive substances (Gallo et al., 1995; Ma et al., 1997a) able to affect the release of LHRH.

Evidence now exists that trophic factors signaling through receptor tyrosine kinases play a pivotal role in the cell-cell interactive mechanism by which astrocytes regulate LHRH neuronal function (Olson et al., 1995; Tsai et al., 1995; Voigt et al., 1996). For instance, transforming growth factor $\alpha$ (TGF $\alpha)$, a member of the epidermal growth factor (EGF) family (Massague, 1990), is synthesized in hypothalamic astrocytes and specialized glioependymal cells lining the third ventricle of the brain (Ma et al., 1992, 1994a), and promotes LHRH release indirectly, via juxtacrine-paracrine stimulation of glial cells containing EGF (erbB-1) receptors (Ma et al., 1994a, 1997a; Voigt et al., 1996). The ME appears to be an important site at which TGF $\alpha$ exerts its neuroendocrine actions. When cells genetically modified to secrete the growth factor are grafted into this region, puberty is advanced (Rage et al., 1997). Conversely, puberty is delayed by inhibition of erbB-1 tyrosine kinase activity targeted to the median eminence (Ma et al., 1992).

Signaling through erbB receptors is not, however, an isolated process involving the activation of a single receptor by a single ligand. Recent studies have shown that ligand binding to a particular erbB receptor involves the recruitment of related erbB receptors (Carraway and Cantley, 1994; Burden and Yarden, 1997). In addition to erbB-1 that binds EGF, TGF $\alpha$, and four other EGF-related ligands (Carpenter and Cohen, 1990), the family of erbB tyrosine kinase receptors includes erbB-2 (Barg- 
mann et al., 1986b), erbB-3 (Kraus et al., 1989; Plowman et al., 1990), and erbB-4 (Plowman et al., 1993a). Whereas erbB-3 and erbB-4 bind a large group of structurally related, EGF-like peptides collectively known as neuregulins (NRGs) (Wen et al., 1992; Marchionni et al., 1993; Burden and Yarden, 1997; Carraway et al., 1997; Chang et al., 1997), no ligand for erbB-2 has yet been identified (Carraway and Cantley, 1994). Rather than acting as a typical receptor, erbB-2 appears to function as an auxiliary molecule (Karunagaran et al., 1996) recruited by ligand-induced activation of both erbB-1 and NRG (erbB-3 and erbB-4) receptors (Akiyama et al., 1988; Beerli et al., 1995; Karunagaran et al., 1996; Riese et al., 1996; Zhang et al., 1996). We show here that expression of the genes encoding erbB- 2 and erbB- 4 within the hypothalamus is mostly astroglial and that it selectively increases in this brain region during the phases of development that precede and accompany the advent of female sexual maturation. This increase in gene expression is sequentially determined by both gonad-independent and sex steroid-regulated mechanisms. Both NRGs and TGF $\alpha$ are equally effective in stimulating astrocytic release of $\mathrm{PGE}_{2}$, an eicosanoid involved in mediating neurotransmitter-induced LHRH release. Disruption of erbB-2 synthesis by an antisense oligodeoxynucleotide not only prevents $\mathrm{PGE}_{2}$ release in response to $\mathrm{NRG}$ stimulation and the ability of astrocytes to stimulate $\mathrm{LHRH}$ release via diffusible factors, but significantly, it also delays the onset of puberty.

Parts of this work have been published previously (Ma et al., 1997b).

\section{MATERIALS AND METHODS}

\section{Animals}

Immature and pregnant female rats of the Sprague Dawley strain were purchased from B \& K Universal, Inc. (Fremont, CA). They were housed in a room with controlled photoperiod (14/10 hr light/dark cycle; lights on from 5:00 A.M. to 7:00 P.M.) and temperature $\left(23-25^{\circ} \mathrm{C}\right)$. Animals were allowed access to tap water and pelleted rat chow ad libitum.

\section{Cell culture}

Hypothalamic and cerebrocortical astrocytes were purified from 1- to 2-d-old rats, as described previously (Ma et al., 1994a). In brief, brain tissues were mechanically dissociated using a Stomacher 80 blender (Tekmar, Cincinnati, $\mathrm{OH}$ ) at $80 \%$ power for $2-3 \mathrm{~min}$. The cell suspension was filtered first through a $230 \mu \mathrm{m}$ metal sieve (Bellco, Vineland, $\mathrm{NJ}$ ) and then through a $130 \mu \mathrm{m}$ nylon mesh filter (Nitex, Elmsford, NJ). The cells were plated in $75 \mathrm{~cm}$ culture flasks (Corning Costar Co., Acton, MA) and cultured in DMEM-F-12 medium (1:1, vol/vol) supplemented with $10 \%$ calf serum under an atmosphere of $5 \% \mathrm{CO}_{2}-95 \%$ air at $37^{\circ} \mathrm{C}$. Upon reaching confluency $(8-10 \mathrm{~d})$, the astrocytes were isolated from other contaminating cells by first shaking the flasks at $250 \mathrm{rpm}$ for $6 \mathrm{hr}$, replacing the medium, and then shaking again for another $18 \mathrm{hr}$. Thereafter, the astrocytes were replated in six-well plates at 800,000 cells per well. Upon reaching $80-90 \%$ confluency, the medium was replaced with a serum-free, astrocyte defined medium (ADM), and the astrocytes were used 1-2 d later for the experiments. ADM consisted of DMEM (lacking glutamate and phenol red) supplemented with L-glutamine (2 $\mathrm{mm})$, HEPES $(15 \mathrm{~mm})$, insulin $(5 \mu \mathrm{g} / \mathrm{ml})$, and putrescine $(100 \mu \mathrm{M})$. The cultures were more than $95 \%$ pure, as assessed by the number of cells immunopositive for the astrocytic marker, glial fibrillary acidic protein (Ma et al., 1994a).

The immortalized LHRH-producing cell line GT1-1 (kindly provided by Dr. Richard Weiner, University of California at San Francisco, San Francisco, CA) was used to assess the effect of astrocyte-derived substances on LHRH release. The cells were seeded in 24 -well plates (100,000 cells per well) and cultured in DMEM containing $10 \%$ fetal calf serum, penicillin $(100 \mathrm{U} / \mathrm{ml})$, and streptomycin $(100 \mu \mathrm{g} / \mathrm{ml})$. Upon reaching $50-60 \%$ confluency, they were transferred to a serum-free, neuronal defined medium (NDM) for $24 \mathrm{hr}$, before being used for the experiments. NDM consisted of glutamate-free DMEM supplemented with transferrin $(100 \mu \mathrm{g} / \mathrm{ml})$, putrescine $(100 \mu \mathrm{M})$, L-glutamine $(2 \mathrm{mM})$, so- dium selenite (30 nM), and insulin (5 $\mu \mathrm{g} / \mathrm{ml})$ (Berg-von der Emde et al., 1995).

MCF-7 cells (American Type Culture Collection, Manassas, VA; HTB-22, human breast adenocarcinoma), used as a positive control to verify the ability of NRG1 to induce erbB-2 tyrosine phosphorylation, were cultured in DMEM supplemented with $10 \%$ fetal calf serum and 2 mM L-glutamine.

\section{Cell treatments}

Astrocytes and MCF-7 cells. (1) To document the ability of TGF $\alpha$ and NRG1 to induce erbB-1, erbB-2, or erbB-4 tyrosine phosphorylation, hypothalamic and cortical astrocytes and MCF-7 cells were seeded into $100 \mathrm{~mm}$ tissue culture dishes and grown to $\sim 80 \%$ confluency. The cells were then transferred to serum-free medium and cultured for $24 \mathrm{hr}$ before treating them with $\mathrm{TGF} \alpha$ or the $\mathrm{NRG} 1$, neu differentiation factor- $\beta 2$ (NDF- $\beta 2 ; 100 \mathrm{ng} / \mathrm{ml}, 5 \mathrm{~min}$ ). Thereafter, the cells were washed with PBS and solubilized in radioimmunoprecipitation assay (RIPA) buffer (1\% Nonidet P-40, $0.5 \%$ sodium deoxycholate, and $0.1 \%$ SDS in PBS, pH 7.4) containing $1 \mu \mathrm{M}$ PMSF, $20 \mu \mathrm{g} / \mathrm{ml}$ aprotinin $(0.09 \mathrm{IU} / \mathrm{ml})$, and $1 \mathrm{~mm}$ sodium orthovanadate. The solubilized proteins were stored at $-85^{\circ} \mathrm{C}$ until immunoprecipitation and electrophoretic separation of the tyrosine phosphorylated species (see below). (2) The ability of NRG1 to stimulate the release of $\mathrm{PGE}_{2}$ from hypothalamic astrocytes was examined by treating the cells with the NDF isoforms $\beta 1, \beta 2$, and $\alpha 2$ and comparing the response with that to TGF $\alpha$ administered at a similar dose. The possibility that NRG1 may facilitate the effect of TGF $\alpha$ on $\mathrm{PGE}_{2}$ release was also examined by treating astrocytes with an ineffective concentration of NDF- $\beta 2(10 \mathrm{ng} / \mathrm{ml})$ in combination with increasing doses of TGF $\alpha(5,10$, and, $20 \mathrm{ng} / \mathrm{ml})$. (3) To determine the importance of erbB-2 in erbB-4- mediated NRG signaling in hypothalamic astrocytes, the astrocytes were treated with NDF- $\beta 2(50 \mathrm{ng} / \mathrm{ml})$ for $16 \mathrm{hr}$ in the presence of a 21-mer antisense oligodeoxynucleotide [erbB-2 oligodeoxynucleotide (ODN); 5'-CATGATGATCATTGCGGCTCC-3'; 1 $\mu \mathrm{M}$ ] encompassing the translation initiation codon [nucleotides (nt) -9 to +12] of rat erbB-2 mRNA (Suen and Hung, 1990). At the end of the treatment, the medium was collected for $\mathrm{PGE}_{2}$ measurement (Campbell and Ojeda, 1987). An oligodeoxynucleotide containing the same nucleotides but in a random order was used as a control. The sequence of this oligodeoxynucleotide has no similarity to any other mammalian sequence thus far deposited in GenBank. The effectiveness of the erbB-2 ODN to selectively disrupt erbB-2 synthesis was assessed by treating hypothalamic astrocytes for $16 \mathrm{hr}$ with either the ODN or the scrambled sequence and then subjecting the cells to a $5 \mathrm{~min}$ exposure to NDF- $\beta 2$. Thereafter, the cells were processed as outlined above for subsequent immunoprecipitation of erbB- 2 and erbB- 4 and determination of phosphorylated receptor content.

GT1-1 cells. These cells were used to determine whether NRG is able to act directly on LHRH-secreting neurons to stimulate LHRH release or whether it does so via a glial intermediacy. The cells were treated with either NDF- $\beta 2(50 \mathrm{ng} / \mathrm{ml})$ or a culture medium conditioned by hypothalamic astrocytes treated for $16 \mathrm{hr}$ with NDF- $\beta 2$ alone, or NDF- $\beta 2$ in the presence of the above described erbB-2 antisense oligodeoxynucleotide. After treating the GT1-1 cells for 30 min, the medium was collected for LHRH measurement (Ojeda et al., 1986a). A conditioned medium derived from hypothalamic astrocytes treated with TGF $\alpha$, known to induce LHRH release via its content of $\mathrm{PGE}_{2}$ (Ma et al., 1997a) was also applied to GT1-1 cells as a positive control for LHRH release.

\section{Cell transfection}

Because NRG1 induces erbB-2 tyrosine phosphorylation in hypothalamic astrocytes, which contain erbB-4 receptors, but not in cerebrocortical astrocytes, which lack these receptors, cortical astrocytes were transfected with cNHER4, a plasmid that encodes the human erbB-4 receptor, to document the requirement of erbB-4 for NRG1 signaling in astrocytes. The cells were seeded into $60 \mathrm{~mm}$ plates, grown to $80 \%$ confluency, and transfected for $5 \mathrm{hr}$ with Lipofectamine (Life Technologies, Grand Island, NY), as described previously (Mayerhofer et al., 1996). Forty-eight hours after transfection, the astrocytes were treated with NDF- $\beta 2$ (100 ng/ml, $5 \mathrm{~min})$ and analyzed for erbB-2 tyrosine phosphorylation.

\section{Reverse transcription-PCR of NRGs and erbB receptors}

NRGs. A 251 bp NRG1 cDNA fragment was amplified from total RNA from either hypothalamic tissue or hypothalamic astrocytes. The primers used were 20-mer oligodeoxynucleotides corresponding to nt 532-551 (5' 
primer) and 764-783 (3' primer) in the extracellular-encoding region of the NRG1 gene (Wen et al., 1992) that is common to all described NRG mRNA isoforms (Wen et al., 1994). To obtain cDNAs complementary to the $\alpha$ and $\beta$ forms of NRG2 mRNA (314 and $270 \mathrm{bp}$, respectively), we used 5' primers, specific for each form: 5'-AAACGGATTCTTCGGACAGA-3', corresponding to nt 247-266 in the $\alpha$ form; 5'CGAAGGCATCAACCAACTCT-3', corresponding to nt 989-1008 in the $\beta$ form; and a common $3^{\prime}$ primer, 5'-TGGTGGGCCGGACACATGTT-3', complementary to nt 541-560 in the $\alpha$ form (Chang et al., 1997). Total RNA isolated from the hypothalamus or hippocampus was used as the template. To isolate an NRG3 cDNA, we used RNA from the hypothalamus, hypothalamic astrocytes, human keratinocytes, and rat liver, and 21-mer primers that amplify a region (nt 1260-1627) including the entire transmembrane-encoding portion of murine NRG3 mRNA (Zhang et al., 1997). The 5' primer used was 5'-CTACCAAGGAGTCCGTTGTGA-3'; the $3^{\prime}$ primer was $5^{\prime}$-TTGACTCCATTATTTTCTCCA-3'.

ErbBs. A 322 bp erbB-2 and a 168 bp erbB-4 cDNA fragment were generated from total RNA from either hypothalamic tissue or hypothalamic astrocytes. A 331 bp erbB-3 DNA was obtained from liver RNA. The 5' primer (5'-CAGTGTGTCAACTGCAGTCA-3') used to amplify erbB-2 corresponds to nucleotides 1610-1629 in the rat erbB-2 mRNA sequence (Bargmann et al., 1986b). The 3' primer (5'-CAGGAGTGGGTGCAGTTGAT-3') is complementary to nucleotides 1913-1932. The primers used to amplify erbB-3 and erbB-4 DNA fragments were synthesized based on human erbB-3 and erbB-4 sequences. The $5^{\prime}$ primer is a common 20-mer oligonucleotide (5'-AACTGCACCCAGGGGTGTAA- $3^{\prime}$ ) corresponding to a highly conserved region (nt 1891-1910 in the human erbB-4 gene) in the extracellular domainencoding portion of both genes (Kraus et al., 1989; Plowman et al., 1993a). In the rat sequence, nt 12 of this primer $(G)$ is substituted for an A. The $3^{\prime}$ primers used are specific to each mRNA. The erbB-3 3' primer (20-mer; 5-AAATCCCCTTGTGGACAGTT-3') is complementary to nt 2361-2380 in the intracellular domain of the erbB-3 mRNA sequence (Kraus et al., 1989). The 20-mer $3^{\prime}$ primer of erbB-4 (5'AACATAAACAGCAAATGTCA-3') is complementary to nt 20392058 in the transmembrane domain of human erbB-4 (Plowman et al., 1993a). Nucleotides 1 and 10 in this primer differ from the recently published rat erbB-4 sequence at positions 2049 and 2058 (GenBank accession number AF041838).

\section{RNase protection assay-solution hybridization}

Immediately after decapitation of the rats, brains were removed, and the medial basal hypothalamic area including the $\mathrm{ME}$, arcuate nucleus (ARC), and the ventromedial nuclei of the hypothalamus (VMH) (referred to as ME-ARC) was collected, as described previously (Ma et al., 1992). Cerebral cortex was used as a control. All dissected tissues were quickly frozen on dry ice and stored at $-85^{\circ} \mathrm{C}$ until RNA isolation.

Total RNA from brain tissue and cultured cells was isolated as reported previously (Lara et al., 1990; Ojeda et al., 1991; Ma et al., 1994a). The RNase protection assay used has been described previously in detail (Ma et al., 1996). In brief, ${ }^{32}$ P-UTP-labeled rat erbB-2 and erbB-4 antisense RNA probes were purified using a Fullengther apparatus (Biokey Co., Portland, OR), as recommended (Ma et al., 1996). Each probe $(500,000 \mathrm{cpm})$ was hybridized to RNA samples $(5 \mu \mathrm{g} /$ tube $)$ or to different amounts of in vitro synthesized sense RNA for $18-20 \mathrm{hr}$ at $45^{\circ} \mathrm{C}$. The tissue RNA samples were simultaneously hybridized to $5000 \mathrm{cpm}$ of a cyclophilin antisense cRNA probe to correct for procedural variability (Ma et al., 1996), because cyclophilin mRNA is constitutively expressed in brain and other tissues (Danielson et al., 1988). Upon completion of the hybridization, the samples were treated with ribonucleases A and T1 to digest unhybridized RNA species. The protected cRNA fragments were separated by polyacrylamide gel electrophoresis (5 or $7 \%$ acrylamide, $7 \mathrm{M}$ urea), and the hybridization signals were visualized by exposing the dried gels to Reflection x-ray film (NEN, Boston, MA). Quantitation of the signals was performed as described previously (Ma et al., 1994a), using an edited version of the NIH Image program (CorreaRotter et al., 1992).

\section{Probes}

To prepare erbB riboprobes labeled with ${ }^{32} \mathrm{P}-\mathrm{UTP}$ (for RNase protection assay) or ${ }^{35}$ S-UTP (for hybridization histochemistry), we used DNA templates corresponding to sequences contained in the coding region of each erbB mRNA. An erbB-2 DNA template was prepared by cloning a BamHI 422 bp fragment of a rat erbB-2 cDNA (Bargmann et al., 1986a)
(pSV2NeuT; a generous gift of Dr. R. A. Weinberg, Whitehead Institute for Biomedical Research, Cambridge, MA) into the BamHI site of pGEM-3Z. ErbB-3 and erbB-4 cDNA templates generated by Reverse transcription (RT)-PCR (see above) were cloned into the riboprobe vector pGEM-T. The cyclophilin cDNA template used for the transcription of cyclophilin cRNA probes was a 132 bp NcoI DNA fragment excised from a rat cyclophilin cDNA (Danielson et al., 1988) and cloned into the riboprobe vector pGEM-5zf(-).

\section{Hybridization histochemistry}

The procedure used (Simmons et al., 1989) has been reported in detail previously (Ma et al., 1992, 1994b). Briefly, the brains were transcardially perfused with $4 \%$ paraformaldehyde in borate buffer, $\mathrm{pH} 9.5$. After an overnight post-fixation in the same fixative containing $10 \%$ sucrose, the brains were blocked and stored at $-85^{\circ} \mathrm{C}$ until being coronally sectioned at $20-25 \mu \mathrm{m}$ using a sliding microtome. The sections were then mounted on Superfrost Plus slides (Fisher Scientific, Kent, WA) and dried overnight under vacuum before hybridization. After prehybridization (Simmons et al., 1989), each slide was overlaid with $70 \mu \mathrm{l}$ of hybridization solution containing $50 \%$ formamide, $0.25 \mathrm{M} \mathrm{NaCl}, 10 \mathrm{~mm}$ Tris, $\mathrm{pH} 8.0,10$ mM EDTA, $2 \times$ Denhardt's solution, and the riboprobe of interest $(1 \times$ $10^{7} \mathrm{cpm} / \mathrm{ml}$ ). Thereafter, the slides were hybridized for $18-20 \mathrm{hr}$ at $55^{\circ} \mathrm{C}$. Posthybridization washes were performed as reported previously (Simmons et al., 1989; Ma et al., 1992, 1994b). After dehydration in graded alcohols, the slides were dipped in Kodak NTB-2 emulsion (Eastman Kodak, Rochester, NY) and developed after 3 weeks of exposure. Controls sections were hybridized with erbB-2 or erbB-4 sense RNA probes.

\section{Immunohistochemistry-confocal microscopy}

The brains of peripubertal female rats were fixed by transcardiac perfusion with Zamboni's fixative (Ma et al., 1994b) and subjected to double immunohistofluorescence using $50 \mu \mathrm{m}$ floating vibratome sections and a procedure described previously (Jung et al., 1997). ErbB-2 was detected with a monoclonal antibody $(\mathrm{Ab})$ (c-neu, Ab-3; Oncogene Research Products, Cambridge, MA) diluted 1:100. ErbB-4 was detected with monoclonal antibody c-erbB-4, Ab-1 (also at a 1:100 dilution; NeoMarkers, Union City, CA). Astrocytes were identified with a monoclonal antibody to GFAP (1:1000; Sigma, St Louis, MO). After an overnight incubation at $4^{\circ} \mathrm{C}$ with either erbB- 2 or erbB- 4 antibodies, the reactions were developed with a Texas Red-conjugated goat anti-mouse gamma globulin (1:200, $1 \mathrm{hr}$ at room temperature; Jackson ImmunoResearch, West Grove, PA). After extensive washes, the sections were incubated (overnight at $4^{\circ} \mathrm{C}$ ) with the GFAP antibody. Because this antibody was also monoclonal, we did not use a secondary antibody to develop the reaction, but instead labeled the GFAP antibody directly with Oregon Green 488 (Molecular Probes, Eugene, OR), according to the manufacturer's instructions, to a specific activity of 2.7 molecules of dye per molecule of antibody protein. Immunofluorescence controls consisted of sections incubated in the absence of the primary antibodies.

Confocal images were acquired using a Leica (Nussloch, Germany) TCS NT confocal system, with a $25 \times$ NA 0.75 PL FLUOTAR objective. FITC and Texas Red were imaged simultaneously in most cases, using the 488 and $568 \mathrm{~nm}$ lines of an argon and krypton gas lasers, respectively, for excitation, a double dichroic at 488 and $568 \mathrm{~nm}$, and a reflective mirror for wavelengths $<580 \mathrm{~nm}$ in front of the first detection channel. A bandpass emission filter of $530 \pm 30 \mathrm{~nm}$ was used for Oregon Green, and a long-pass filter at $590 \mathrm{~nm}$ was used for Texas Red. The intensity of the excitation light in each channel was adjusted so that the contribution of fluorescein to light detected in the Texas Red channel was negligible. Typically, 16 optical sections 1-3 $\mu \mathrm{m}$ apart were acquired for each image. Colors were merged and sections were projected into a single plane using MetaMorph (Universal Imaging, West Chester, PA). Images were further processed using Photoshop 5.0 (Adobe Systems, San Jose, CA).

\section{ErbB-1, erbB-2, and erbB-4 tyrosine phosphorylation}

For erbB-1, erbB-2, and erbB-4 kinase assays, lysates from treated cells were microf uged at $4^{\circ} \mathrm{C}$ for $5 \mathrm{~min}$, and the supernatants were reacted for $3 \mathrm{hr}$ at room temperature with a slurry of protein A-Sepharose that had been preabsorbed to antibodies against either erbB-1 (polyclonal Ab 1383; a gift from Shelton Earp, Department of Pharmacology, University of North Carolina, Chapel Hill, NC), erbB-2 (polyclonal Ab 1275, provided by G. Clinton, Department of Biochemistry, Oregon Health Sciences University, Portland, OR; or SC-284, purchased from Santa Cruz Biotechnology, Santa Cruz, CA), or erbB-4 (SC-283; Santa Cruz Bio- 
technology). Immunoprecipitated proteins were electrophoresed on a $8 \%$ SDS-polyacrylamide minigel and then transferred onto a nitrocellulose membrane. After blocking for $1 \mathrm{hr}$ with $2 \% \mathrm{BSA}-0.2 \%$ Tween 20 in Tris-buffered saline (TBS), the membranes were probed with a monoclonal phosphotyrosine antibody (4G10, kindly provided by Dr. David Kaplan, Montreal Neurological Institute, Montreal, Canada; or PY-20, purchased from Santa Cruz Biotechnology) and then with an anti-mouse HRP-linked antibody (Boehringer Mannheim, Indianapolis, IN), as described previously (Ma et al., 1994b). After several extensive washes, tyrosine phosphorylated proteins were detected using the Enhanced Chemiluminescence system from Amersham Pharmacia Biotech (Arlington Heights, IL).

\section{Cross-linking of erbB-2 and erbB-4 receptors}

Hypothalamic astrocytes were maintained in serum-containing medium in $100 \mathrm{~mm}$ culture dishes until they reached $\sim 90 \%$ confluency. They were then cultured in ADM (see above) for $48 \mathrm{hr}$ before treatment with $\mathrm{NDF} \beta 2(500 \mathrm{ng} / \mathrm{ml})$ for $3 \mathrm{~min}$ at $37^{\circ} \mathrm{C}$. At the end of this treatment, the astrocytes were exposed to bis (sulfosuccinimidyl) suberate $\left(\mathrm{BS}^{3}\right)(2 \mathrm{mM}$; Pierce, Rockford, IL), a noncleavable, amine-reactive cross-linker (Staros and Kakkad, 1983), for $2 \mathrm{~min}$ at room temperature, followed by incubation on ice for $30 \mathrm{~min}$. Thereafter, the cells were washed with ice-cold PBS, collected into PBS, pelleted by brief centrifugation, and lysed in RIPA buffer. The lysates were immunoprecipitated overnight at $4^{\circ} \mathrm{C}$ using rabbit polyclonal antibodies to either erbB-2 (C-Neu, Ab-1; Oncogene Research Products) or erbB-4 (SC-283; Santa Cruz Biotechnology) at 1:200 dilution. For each sample tube, $80 \mu \mathrm{l}$ of protein A-Sepharose (1:1 slurry, in water) was added, and the tubes were tipped for an additional $3 \mathrm{hr}$. Immunoprecipitates were pelleted by microcentrifugation and washed once with ice-cold RIPA and once with ice-cold PBS. Each immunoprecipitate was suspended in $30 \mu \mathrm{l}$ of $\mathrm{H}_{2} \mathrm{O}$ and $15 \mu \mathrm{l}$ of a $3 \times$ concentrated sample buffer (final concentration of $0.0625 \mathrm{M}$ Tris, $\mathrm{pH} 6.8,3 \%$ SDS, $5 \%$ glycerol, and $5 \% \beta$-mercaptoethanol). The protein samples were denatured at $100^{\circ} \mathrm{C}$ for $5 \mathrm{~min}$, and $15 \mu \mathrm{l}$ of each sample was used for SDS-PAGE on a $6 \%$ polyacrylamide gel. Separated proteins were electrophoretically transferred to a Hybond ECL nitrocellulose membrane (Amersham Pharmacia Biotech, Piscataway, NJ), and blocked with $2 \%$ BSA and $0.2 \%$ Tween 20 , in TBS for $1 \mathrm{hr}$ at room temperature. The membranes were then incubated with antibodies, either erbB-2 (mouse monoclonal C-Neu, Ab-3; Oncogene Research Products) or the same erbB-4 used previously for immunoprecipitation (each at 1:200 dilution). After $4 \mathrm{hr}$ incubation at room temperature, the membranes were washed three times (10 min each) with TBS-Tween 20 at room temperature and then incubated with a horseradish peroxidase-linked secondary antibody, diluted 1:5000 with TBS-Tween 20, for $1 \mathrm{hr}$ at room temperature. After washing, the reactions were developed using the SuperSignal Ultra Chemiluminescent Substrate (Pierce).

\section{Ovariectomy and steroid treatment}

The ovaries from early juvenile (22-d-old) rats were removed via a dorsal approach, as described previously (Andrews et al., 1981). Five days after surgery, the rats received a subcutaneously SILASTIC capsule containing corn oil or $17 \beta-\mathrm{E}_{2}$ (Sigma) dissolved in corn oil at a concentration of $400 \mu \mathrm{g} / \mathrm{ml}$ (Andrews et al., 1981). These capsules have been shown (Andrews et al., 1981) to produce circulating levels of $\mathrm{E}_{2}$ similar to those that precede the first preovulatory surge of gonadotropins at puberty in female rats (Andrews et al., 1980). Some animals received a single subcutaneous injection of progesterone (P) (1 mg/rat) $50 \mathrm{hr}$ (12:00 P.M.) after implantation of the $\mathrm{E}_{2}$-containing capsules, to simulate the abrupt increase in plasma $\mathrm{P}$ that occurs in the afternoon of first proestrus, at the time of the first preovulatory surge of gonadotropins (Andrews et al., 1980). Brain tissues were collected 4 hr after the $\mathrm{P}$ injection, i.e., after 54 $\mathrm{hr}$ of estradiol exposure.

\section{Intracerebroventricular infusion of an erbB-2 antisense oligodeoxynucleotide}

To determine the importance of a functional hypothalamic erbB-2 for the timing of puberty, in vivo experiments were performed. The same antisense oligodeoxynucleotide found to be effective in inhibiting the astrocyte response to NRG1 in vitro was chronically infused into the third ventricle of the brain via a stereotaxically implanted infusion cannula (Plastic One, Roanoke, VA) connected to a subcutaneously implanted Alzet mini-osmotic pump (Alzet Corporation, Palo Alto, CA). The pumps (model 2002) have a flow rate of $0.5 \mu \mathrm{l} / \mathrm{hr}$ and a capacity of $200 \mu \mathrm{l}$, resulting in a delivery period of $14 \mathrm{~d}$. Each pump was loaded with artificial CSF (Dalva and Katz, 1994) containing either the erbB-2 antisense oligodeoxynucleotide or the scrambled sequence at 5 $\mu \mathrm{g} / \mathrm{ml}$. Upon connection to the infusion devise and a $4 \mathrm{hr}$ preincubation at $37^{\circ} \mathrm{C}$, the assembly was implanted into 25 -d-old juvenile intact animals. At this time, the prepubertal increase in hypothalamic erbB-2 mRNA levels had not yet begun. Starting on day 30, the animals were monitored daily for vaginal opening (see below). Once vaginal opening occurred, vaginal lavages were obtained to estimate the time of first ovulation (Ojeda and Urbanski, 1994). All animals were killed on the day of first diestrus (defined by the presence of a predominance of leukocytes in the vaginal lavage) after an estrous type of vaginal cytology. This change in vaginal cytology has been shown to be an accurate indication that the first ovulation has taken place (Rage et al., 1997). In all cases, ovulation was confirmed by visual inspection of the ovaries to verify the presence of corpora lutea.

\section{Phases of puberty}

The developmental changes in hypothalamic erbB-2 and erbB-4 gene expression were examined at ages shown previously to correspond to key stages of sexual maturation in the rat (for review, see Ojeda and Urbanski, 1994). The different stages of puberty were defined according to established criteria (Ojeda and Urbanski, 1994). According to these criteria, the juvenile period in the female rat extends from postnatal days 21-30. Thus, the juvenile animals used in this study can be considered as mid-to-late juveniles. Their vaginae were closed, and their uteri weighed $60 \mathrm{mg}$ or less, with no accumulation of intrauterine fluid. Animals with enlarged uteri and detectable intrauterine fluid (an indication of $\mathrm{E}_{2}$ secretion) are considered to be in the early phases of puberty and, thus, are classified as being in an early proestrous (EP) stage, which precedes the day of the first preovulatory surge of gonadotropins. Animals showing a uterus "ballooned" with fluid and a uterine weight of at least $200 \mathrm{mg}$ were considered to be in late proestrus (LP), the phase of puberty during which LHRH and gonadotropins are for the first time discharged as a preovulatory surge. Ovulation occurs in the early morning of the next day (first estrus; E). At this time, the vagina becomes patent and exhibits a cytology of cornified cells. Formation of the first corpora lutea leads to the first diestrus phase of puberty, characterized by a vaginal cytology showing a predominance of leukocytes and the presence of fresh corpora lutea in the ovaries.

\section{Statistics}

Changes in erbB-2 or erbB-4 mRNA levels during different stages of sexual development or in response to gonadal steroid treatments were analyzed by a one-way ANOVA, followed by the Student-NeumanKeuls multiple comparison test for unequal replications.

\section{RESULTS}

\section{NRGs and erbB mRNAs are expressed in the hypothalamus of immature female rats}

To determine whether members of the NRG-erbB signaling complex are expressed in the hypothalamus of prepubertal female rats, total RNA from this region was subjected to RT-PCR using primers complementary to sequences contained within the NRG (NRG1, NRG2, and NRG3), erbB-2, erbB-3, and erbB-4 mRNA coding regions. With the exception of the NRG2 and erbB-3 genes, all other components of the signaling module were found to be expressed in the hypothalamus, as evidenced by the amplification of cDNA fragments of the expected size (Fig. 1) and their identification by sequencing (data not shown). RT-PCR amplification of RNA from isolated hypothalamic astrocytes yielded an identical expression profile (data not shown). Although the primers used to detect NRG2 mRNA in hypothalamic tissue yielded PCR products of a size similar to the NRG2 $\alpha$ and $\beta$ cDNAs amplified from hippocampus (Fig. 1), sequencing of several of these hypothalamic DNA fragments revealed that they did not contain the NRG2 sequence. On the other hand, failure to detect erbB-3 mRNA in the hypothalamus was not because of ineffective primers or inadequate PCR conditions, because an erbB-3 cDNA was readily amplified from tissues known to express the erbB-3 


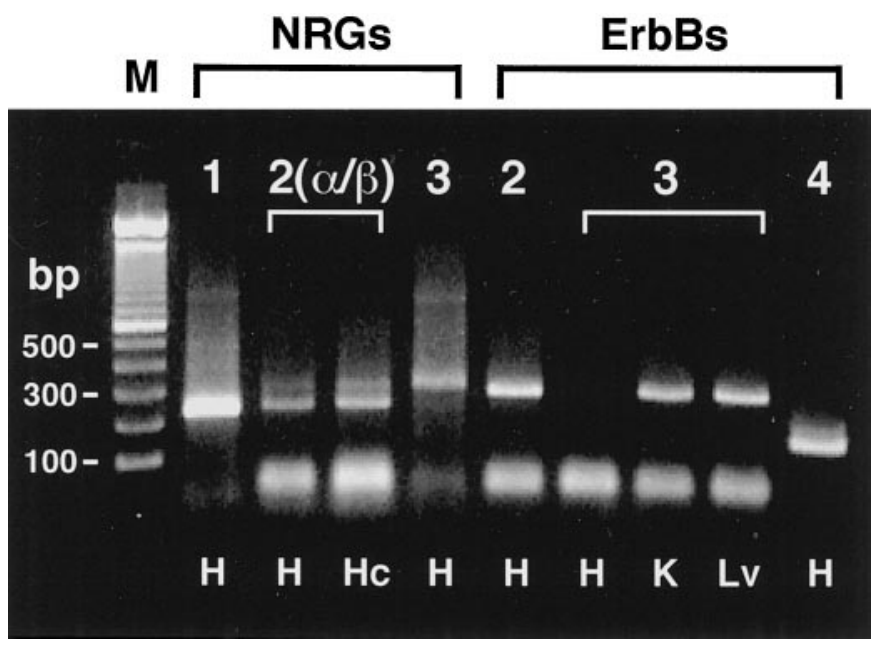

Figure 1. Detection by RT-PCR of NRGs and erbB mRNAs in the medial basal hypothalamus of late juvenile 28 - to 30 -d-old female rats. $M$, DNA molecular size markers. NRG1, 268 bp; NRG2 $\alpha, 314$ bp; NRG2 $\beta$, 270 bp; NRG3, 371 bp; erbB-2, 323 bp; erbB-3, 337 bp; and erbB-4, 168 bp. $H$, Hypothalamus; $H c$, hippocampus; $K$, human keratinocytes; $L v$, rat liver; $b p$, base pairs.

gene, such as the liver and skin keratinocytes (Fig. 1). Thus, neither the hypothalamus of immature rats nor isolated hypothalamic astrocytes contain the NRG2 and erbB-3 mRNAs, indicating that, in this region of the brain, NRG-dependent signaling is effected exclusively via NRG1 and NRG3 acting on erbB-2erbB-4 receptors.

\section{Astroglial expression of erbB mRNAs is region-specific}

It was shown previously that hypothalamic astroglial cells differ both molecularly and functionally from astrocytes of regions not involved in neuroendocrine regulation (Ma et al., 1992, 1994a). To determine whether these differences are also manifested in the case of NRG receptors, the relative abundance of the mRNAs encoding erbB-2, erbB-3, and erbB-4 in hypothalamic and cerebrocortical astrocytes in culture was assessed by RNase protection assay. Figure 2 shows that (1) erbB-2 mRNA is much more abundant in hypothalamic than cortical astrocytes, (2) erbB-4 mRNA is only detected in hypothalamic astrocytes, and (3) neither subpopulation of astrocytes expresses the erbB-3 gene. Thus, as suggested by the PCR data, NRG signaling in hypothalamic astrocytes appears to exclude an involvement of erbB-3 receptors.

\section{Localization of erbB-2 and erbB-4 mRNA in the peripubertal female hypothalamus}

Hybridization histochemistry of the brain from prepubertal (28-to 37-d-old) rats demonstrated that erbB-4 mRNA transcripts were more clearly detected in the paraventricular (Fig. $3 A$, arrows), the arcuate nucleus (ARC), and the ventromedial ( $\mathrm{VMH}$ ) and dorsomedial $(\mathrm{DMH})$ nuclei $(B)$ of the hypothalamus. Although in all of these regions some of the hybridization signal, analyzed under bright-field illumination, was seen in neurons, a substantial fraction of the signal was associated with small, dark nuclei, suggesting an astroglial localization. Such a localization was clearly evident in the subependymal region of the third ventricle $(A, B$, small arrowheads) and the median eminence $(B$, large arrowheads). This is a region devoid of neuronal cell bodies that serve as a final common pathway for neurosecretory nerve terminals converging to release their products into the portal vasculature. ErbB-4 mRNA was detected in glial cells located in the intermediate and external layer of the median eminence $(B$, $C$, small and large arrowheads, respectively). In addition to the hypothalamus, erbB-4 mRNA was abundant in the piriform cortex and hippocampus (data not shown). In both of these regions, the mRNA-containing cells appeared to be mostly neurons.

In contrast to erbB-4 mRNA, the hypothalamic distribution of erbB-2 mRNA transcripts was more circumscribed. ErbB-2 mRNA was predominantly detected in ependymal cells lining the third ventricle ( $E, F$, arrowheads) and glia of the median eminence itself $(F$, arrows $)$. Adjacent tissue sections incubated with the respective sense RNA probes showed no hybridization signals $(D, G)$.

\section{Localization of erbB-2 and erbB-4 proteins in the peripubertal female hypothalamus}

Because the medial basal hypothalamic-median eminence region showed an abundance of erbB- 2 and erbB- 4 mRNA transcripts, we examined this region for the presence of erbB-2- and erbB-4immunoreactive cells using immunohistofluorescence followed by confocal microscopy. Both receptor proteins were found in glial cells, in addition to some neurons. ErbB-2 immunoreactivity was abundant in tanycytes lining the wall of the third ventricle (Fig. $4 A, B, F$ ), with immunoreactive material distributed throughout the length of the processes that these cells send to the base of the brain ( $B$, arrows). Astrocytes of the ventral aspect of the median eminence, identified by their content of GFAP (green), were also rich in erbB-2 immunoreactivity $(C-E)$, as were astrocytes located along the walls of the third ventricle adjacent to tanycytes, which were negative for GFAP $(F-I)$. In addition to this location, erbB-2 immunoreactivity was also observed in astrocytes of the medial basal hypothalamus away from the median eminence, especially those surrounding blood vessels $(J-L)$. Scattered neurons containing erbB-2 were also observed ( $A, B$, short arrows).

In agreement with the mRNA localization, erbB-4 immunoreactivity was observed in glial cells of the median eminence (Fig. $5 A, C$, arrowheads) and neurons of the arcuate nucleus $(A, B$, arrows). As in the case of erbB-2, astrocytes of the ventral aspect of the median eminence were found to contain erbB-4 $(D-F)$, as were astrocytes adjacent to the wall of the third ventricle $(G-I)$, and astrocytes of the medial basal hypothalamus $(J-L)$, including those associated with blood vessels $(M)$. No erbB-4 immunoreactivity was detected in tanycytes $(G-I)$, a predominant site of erbB-2 expression.

\section{Hypothalamic levels of erbB-2 and erbB-4 mRNA increase during juvenile and peripubertal development}

To determine whether changes in the hypothalamic gene expression of erbB-2 and erbB-4 may occur in association with female sexual maturation, the tissue content of the encoding mRNAs in this brain region was quantitated by RNase protection assay. The hypothalamic levels of erbB-2 and erbB- 4 mRNA increased for the first time during late juvenile development (postnatal day 28) and then again during the peripubertal period, reaching maximal values in the afternoon of the first proestrous day (LP), i.e., coinciding with the time of the first preovulatory surge of gonadotropins (Fig. 6, top and bottom), previously shown to occur in the afternoon of this day (Ojeda and Urbanski, 1994). The cerebral cortex, a brain region irrelevant to neuroendocrine control, displayed low and unchanging levels of erbB-2 mRNA throughout the juvenile and peripubertal period (Fig. 6, top). Although the 


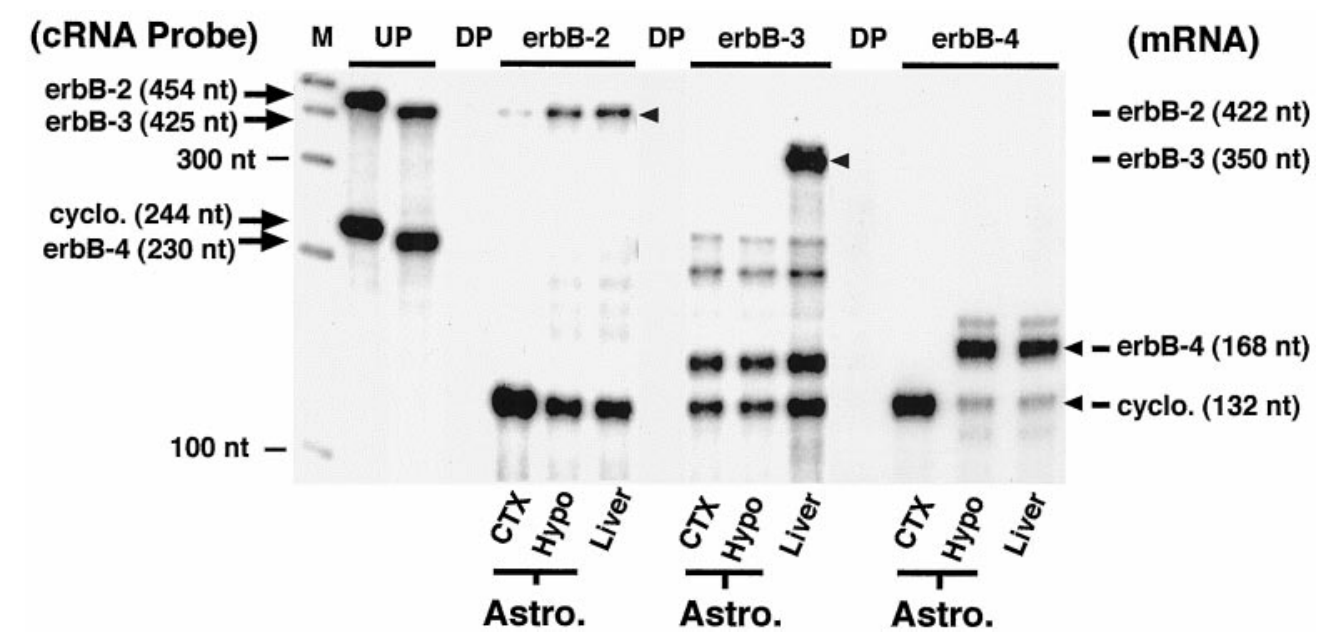

Figure 2. Detection of erbB-2 and erbB-4 mRNAs and absence of erbB-3 mRNA in isolated hypothalamic (Hypo) and cerebrocortical (CTX) astrocytes (Astro.), as assessed by RNase protection assay. $M,{ }^{32} \mathrm{P}$-UTP-labeled RNA molecular size marker; $U P$, undigested cRNA probes; $D P$, digested probes; $c y$ clo, cyclophilin.

Figure 3. Cellular localization of erbB-4 and erbB-2 mRNAs in the brain of peripubertal female rats, as detected by in situ hybridization using ${ }^{35} \mathrm{~S}$-UTP-labeled cRNA probes. Within hypothalamic nuclei, the mRNA was found to be more abundant in cells of the paraventricular nuclei $(A$,arrows $)$ and the $\mathrm{ARC}, \mathrm{VMH}$, and DMH nuclei $(B)$. ErbB-4 mRNA is also diff usely detected throughout the medial basal hypothalamus $(B, C)$ and is more abundantly present in cells of the subependymal region $(A, B$, small arrowheads) and glial cells in the intermediate and external layers of the median eminence $(B$ and $C$, small and large arrowheads, respectively). ErbB-2 transcripts were more abundantly expressed in ependymal cells lining the third ventricle ( $E, F$, arrowheads) and glial cells of the median eminence ( $F$, arrows). $D$ and $G$ depict sections adjacent to $C$ and $F$ hybridized with sense erbB-4 $(D)$ and erbB-2 $(G)$ RNA probes. Scale bars: $B$, $200 \mu \mathrm{m} ; A, C-G, 100 \mu \mathrm{m}$.
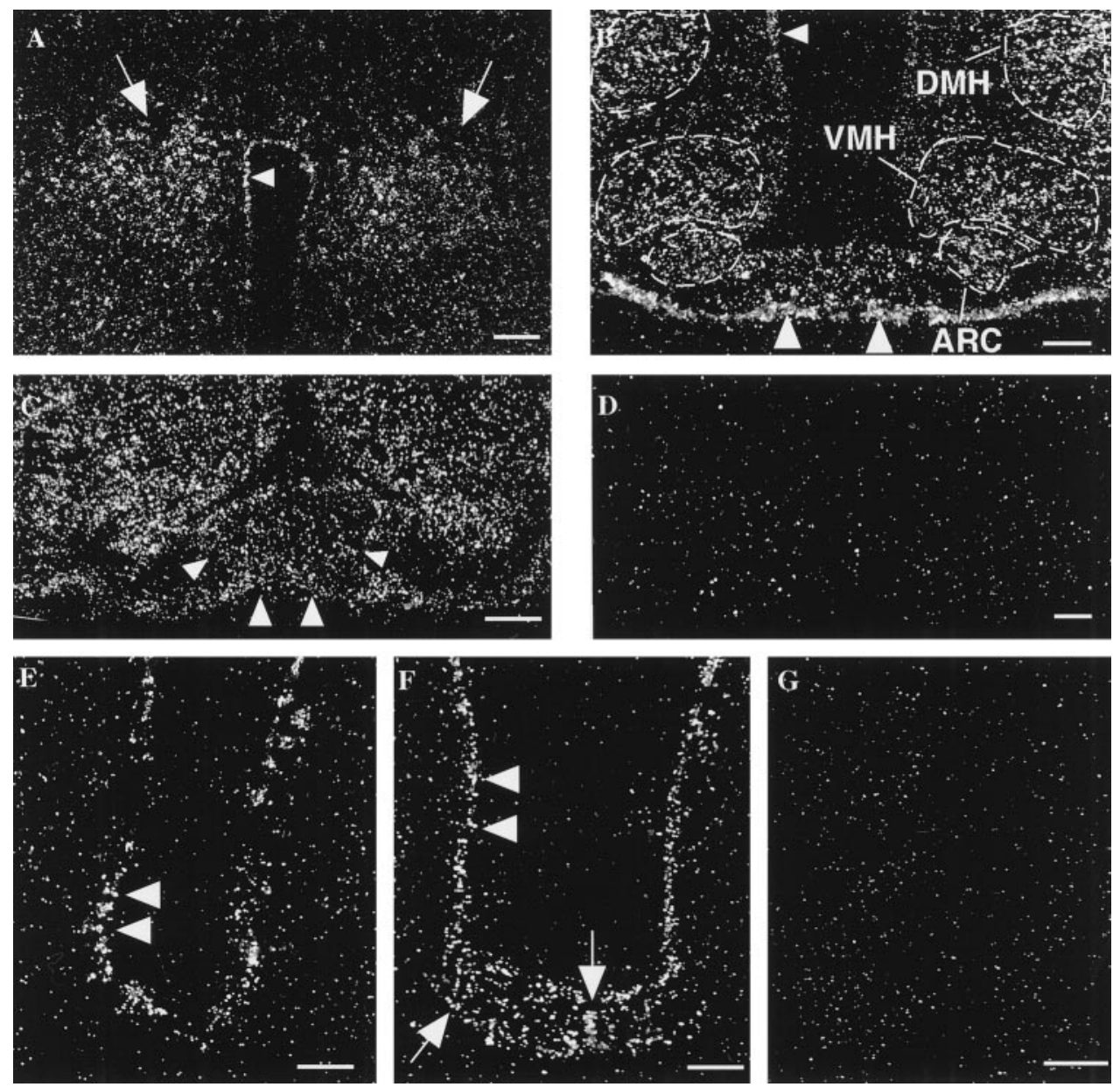

cortical levels of erbB-4 mRNA were higher than those seen in the hypothalamus during midjuvenile development (postnatal day 24-26), they did not increase with the advent of sexual maturity (Fig. 6, bottom).

The juvenile increase in hypothalamic erbB-2 and erbB-4 mRNA levels is gonad-independent, but the peripubertal increase is an ovarian steroid-regulated event.

The juvenile increase in hypothalamic levels of erbB-2 and erbB-4 mRNA occurs at the time when circulating levels of ovarian steroids are low (Table 1). Thus, this initial increase in expression appears to be a centrally driven, gonad-independent event. In contrast, the changes in mRNA content observed during normal puberty occur at the time when the plasma levels of $\mathrm{E}_{2}$ first, and progesterone (P) later, are elevated (Ojeda and Urbanski, 1994), suggesting that at least part of the peripubertal changes in mRNA levels is caused by the rising circulating levels of these ovarian steroids. Mimicking in ovariectomized juvenile rats the preovulatory increase in plasma $\mathrm{E}_{2}$ that occurs at puberty (Andrews et al., 1980), via implantation of $17 \beta-\mathrm{E}_{2}$-containing capsules (Andrews et al., 1981), resulted 2 d later in a significant 

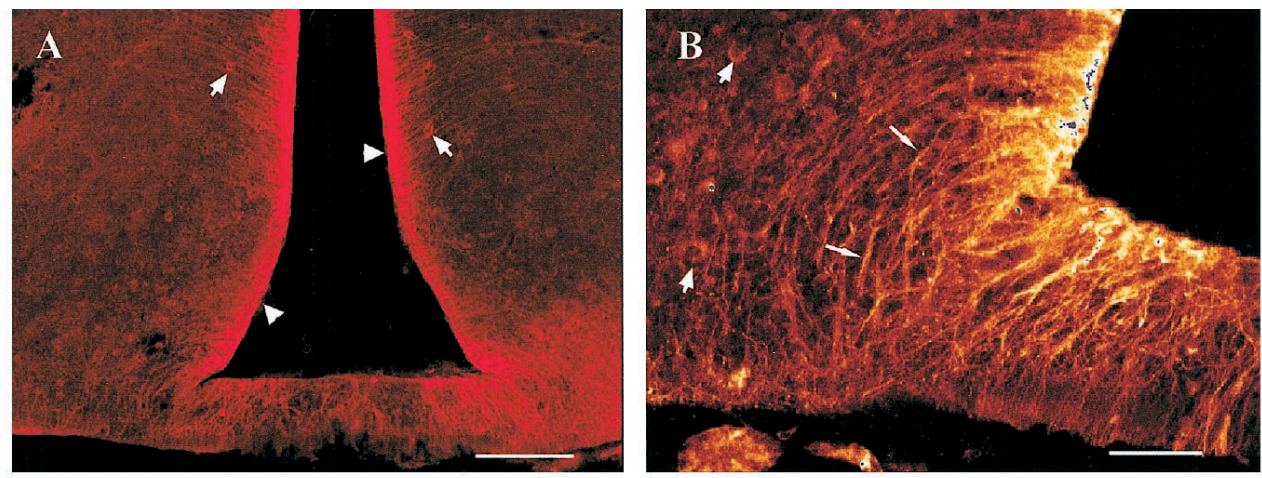
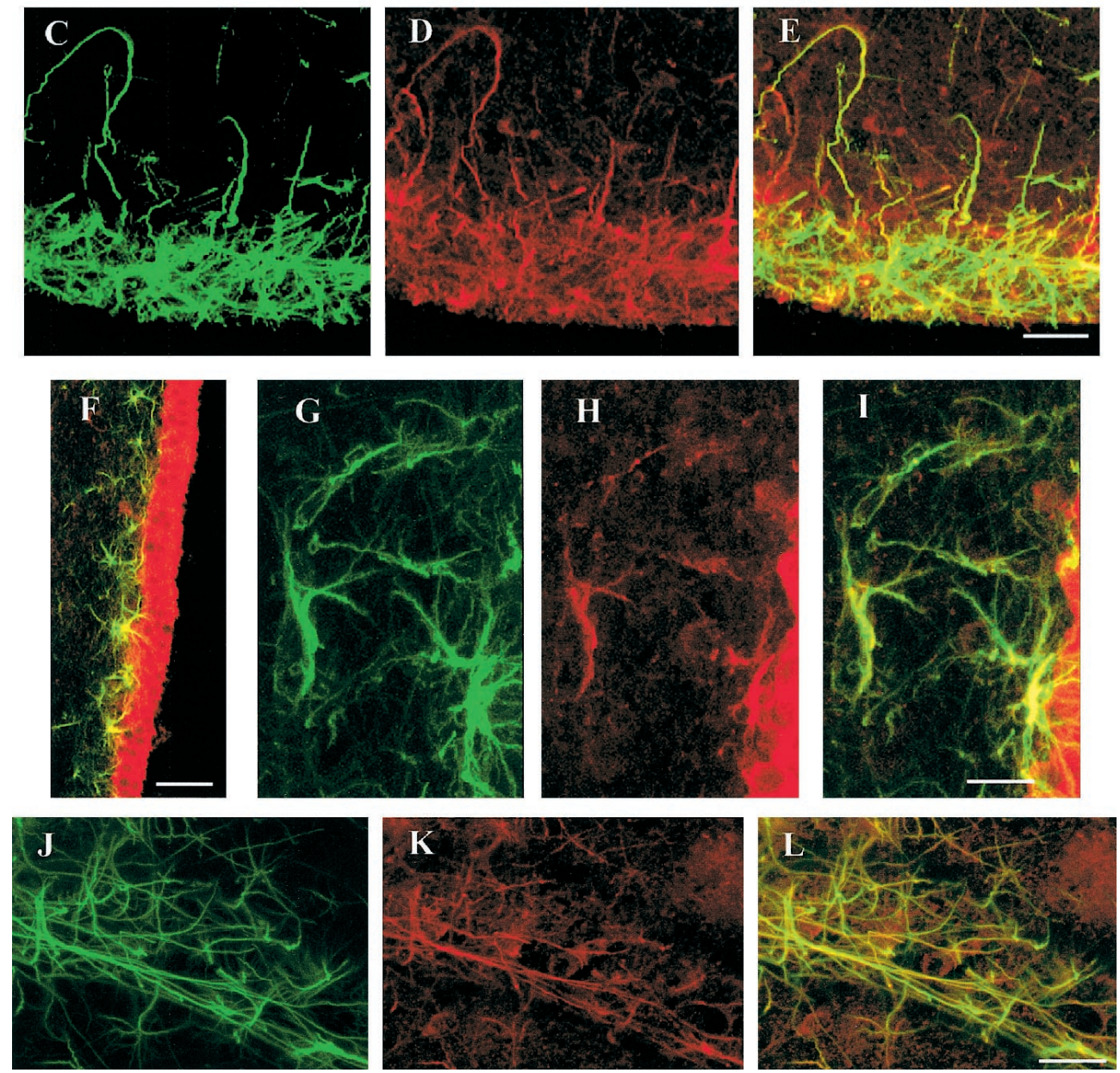

Figure 4. Immunofluorescent confocal microcopy localization of erbB-2 in the medial basal hypothalamus-median eminence region of peripubertal female rats. ErbB-2 was visualized with a monoclonal antibody to an amino acid sequence contained in the human protein, and the reaction was developed with a second antibody conjugated to the fluorochrome Texas Red (red). Astrocytes were identified with a monoclonal antibody to GFAP directly labeled with the fluorochrome Oregon Green 488 (green). $A, B$, Low- and high-magnification views of the medial basal hypothalamus-median eminence region showing abundant erbB-2 immunoreactivity in tanycytes lining the wall of the third ventricle $(A, a r-$ rowheads) and the processes that these cells send to the median eminence $(B$, arrows). Some neurons are also labeled ( $A, B$, short arrows). $C-E$, Presence of erbB-2-immunoreactive material $(D$, red $)$ in astrocytes $(C$, green $)$ of the ventrolateral aspect of the median eminence (images merged in $E$ ). $F$, Presence of erbB-2 in astrocytes adjacent to ependymal cells of the third ventricle. $G-I$, Higher magnification view of erbB-2-positive $(H)$ astrocytes $(G)$ adjacent to the third ventricle (images merged in $I$ ). Notice the abundant erbB-2 immunoreactivity in GFAP-negative tanycytes. $J-L$, Detection of erbB-2 in astrocytes of the medial basal hypothalamus associated with blood vessels. Scale bars: $A, 100 \mu \mathrm{m} ; B, 25 \mu \mathrm{m}$; $C-E, G-L, 10 \mu \mathrm{m} ; F, 40 \mu \mathrm{m}$. increase in hypothalamic erbB-4 mRNA levels but not in erbB-2 mRNA content (Fig. 7), thus reproducing the changes in mRNA content observed during normal puberty before the afternoon preovulatory discharge of gonadotropins (Fig. 6). Administration of a single dose of $\mathrm{P}$ - to $\mathrm{E}_{2}$-treated animals, to produce plasma $\mathrm{P}$ levels similar to those found at the time of the gonadotropin surge (Andrews et al., 1980), resulted in a marked increase in erbB-2 mRNA content but no further change in erbB-4 mRNA levels compared with animals treated with $\mathrm{E}_{2}$ alone (Fig. 7). The changes caused by this sequential $\mathrm{E}_{2}$ plus $\mathrm{P}$ treatment were again similar to those observed in the afternoon of the first proestrus during normal puberty (Fig. 6). P alone was ineffective. Thus, most of the increase in hypothalamic erbB-2 and erbB-4 gene expression at the time of puberty appears to be a gonaddependent event.

\section{NRG-dependent phosphorylation of erbB-2 in astroglia requires the participation of erbB-4}

The mammary tumor cell line MCF-7 that lacks erbB-1 but contains erbB-2 receptors (Karunagaran et al., 1996) failed to respond to EGF with either erbB-1 or erbB-2 tyrosine phosphorylation (Fig. $8 A$, left) but showed a strong increase in erbB-2 phosphorylation upon stimulation with the NRG NDF- $\beta 2$. In contrast to MCF-7 cells, hypothalamic astrocytes, which contain functional erbB-1 receptors (Ma et al., 1994a, 1997a), responded to the EGF relative TGF $\alpha$, with tyrosine phosphorylation of both erbB-1 and erbB-2 (Fig. 8A, right). In addition, they showed erbB-2 and erbB-4 tyrosine phosphorylation when exposed to NDF- $\beta 2$ (Fig. $8 A$, right). Cerebrocortical astrocytes, on the other hand, responded to TGF $\alpha$ with erbB-1 and erbB-2 phosphoryla- 
Figure 5. Immunofluorescence confocal microscopy localization of erbB-4 in the medial basal hypothalamus-median eminence region of peripubertal female rats. ErbB-4 was detected with a monoclonal antibody directed against an epitope in the human erbB-4 sequence, and the reaction was developed with a Texas Red-conjugated secondary antibody. GFAP was detected with a monoclonal antibody directly labeled with $\mathrm{Or}$ egon Green 488. $A$, Low-magnification view showing erbB-4-immunoreactive cells in the arcuate nucleus (arrow) and glial cells of the median eminence ( $a r$ rowhead). $B$, Higher magnification view of the arcuate nucleus showing erbB-4positive neuron-like cells (arrows). C, High-magnification view of erbB-4positive astrocyte-like cells of the median eminence (arrowheads). $D-F$, Presence of erbB-4 in astrocytes of the ventrolateral aspect of the median eminence. Notice that not all astrocytes contain erbB-4 immunoreactivity. $G-I$, Presence of erbB-4 in astrocytes adjacent to tanycytes of the third ventricle. $J-L$, Presence of erbB-4 in astrocytes of the medial basal hypothalamus. $M$, Higher magnification view of erbB-4positive astrocytes associated with blood vessels in the median basal hypothalamus, away from the median eminence. Scale bars: $A, 100 \mu \mathrm{m} ; B, C, 25 \mu \mathrm{m} ; D-I$, $40 \mu \mathrm{m} ; J-L, 20 \mu \mathrm{m} ; M, 30 \mu \mathrm{m}$.
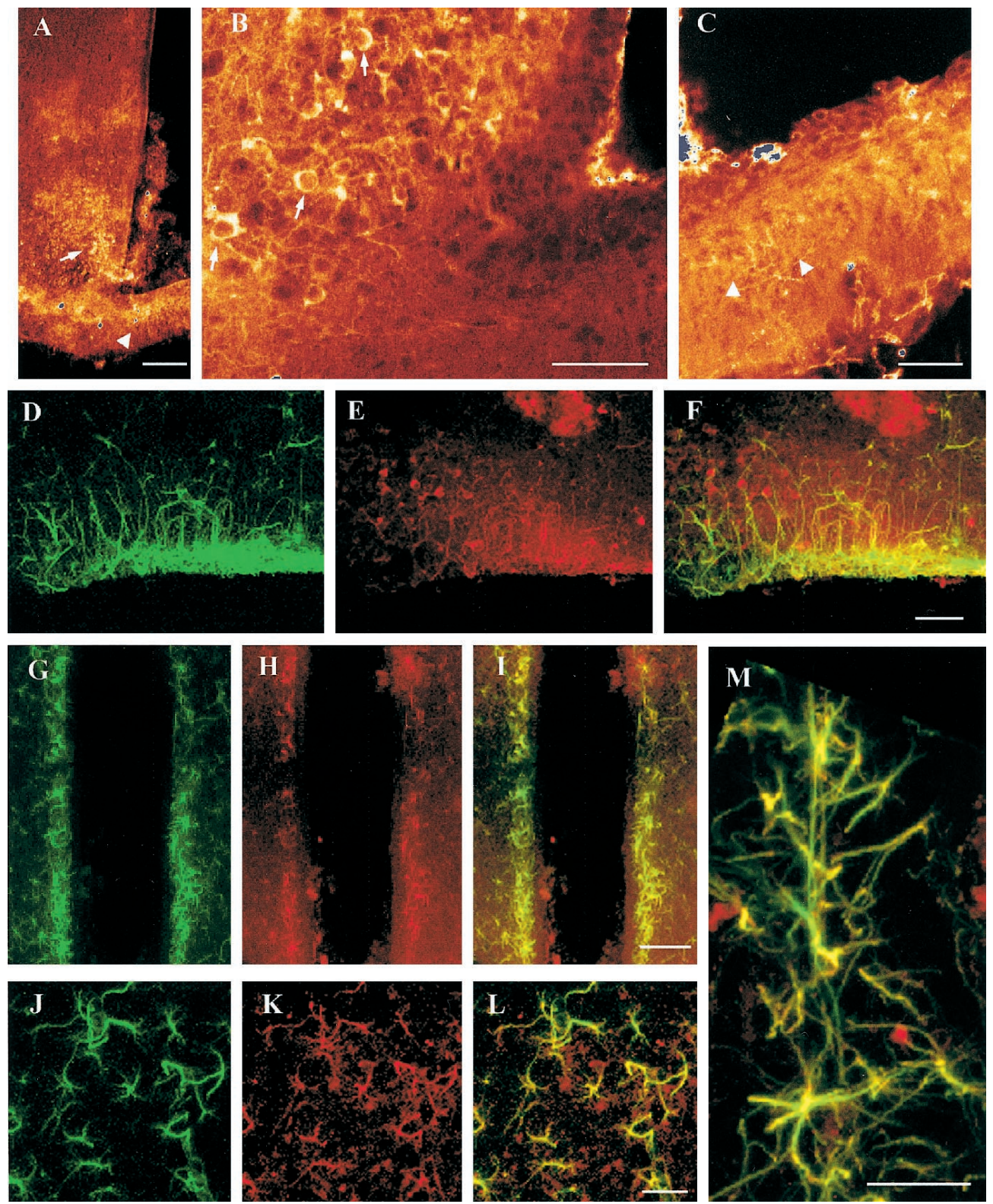

tion (Fig. 8B, left) but showed no erbB-2 phosphorylation upon exposure to NDF- $\beta 2$. Because cortical astrocytes express the erbB-2 but not the erbB-3 or erbB-4 genes (Fig. 2), we reasoned that the inability of NDF- $\beta 2$ to induce erbB- 2 phosphorylation was because of the lack of appropriate neuregulin receptors in these cells. Hypothalamic astrocytes, which express the erbB-4 gene, respond to NDF- $\beta 2$ with erbB-2 phosphorylation (Fig. $8 B$, middle). We, therefore, tested the possibility that the lack of NRG-dependent erbB-2 phosphorylation in cortical astrocytes was caused by the absence of erbB-4. Expression of erbB-4 in these cells, via transient transfection with cNHER4 (Plowman et al., 1993b), a plasmid that contains a cDNA encoding the human erbB-4 receptor, led to an marked increase in both basal and NDF- $\beta 2$-induced erbB-2 phosphorylation (Fig. $8 B$, right).

\section{NRG-dependent activation of erbB-4 in hypothalamic astrocytes involves formation of erbB-4-erbB-2 heterodimeric complexes}

To determine whether exposure of hypothalamic astrocytes to neuregulins results in receptor heterodimerization as shown in cell lines (Spivak-Kroizman et al., 1992; Cohen et al., 1996), astrocytic cultures were treated with NDF- $\beta 2\left(3 \mathrm{~min}\right.$ at $\left.37^{\circ} \mathrm{C}\right)$ followed by cross-linking with bis (sulfosuccinimidyl) suberate (Staros and Kakkad, 1983). Immunoprecipitation of the reactive species with monoclonal antibodies to either erbB-2 or erbB-4, followed by Western blot analysis using antibodies to erbB-2, demonstrated in both cases the presence of a high molecular weight complex of $\sim 365 \mathrm{kDa}$ (Fig. 9, left and middle). To verify the presence of erbB-4 in this complex, the cross-linked species were immunoprecipitated with antibodies to erbB-2, and the Western blot was developed with monoclonal antibodies to erbB-4. The results showed the presence of erbB-4 in a high molecular weight species identical in size to that detected by the erbB-2 antibodies (Fig. 9, right).

\section{Effect of NRG1 isoforms on the secretion of PGE2 from hypothalamic astrocytes}

In a previous study, we showed that TGF $\alpha$-dependent activation of erbB-1 receptors in hypothalamic astrocytes results in the release of $\mathrm{PGE}_{2}$ (Ma et al., 1997a), a prostaglandin involved in 


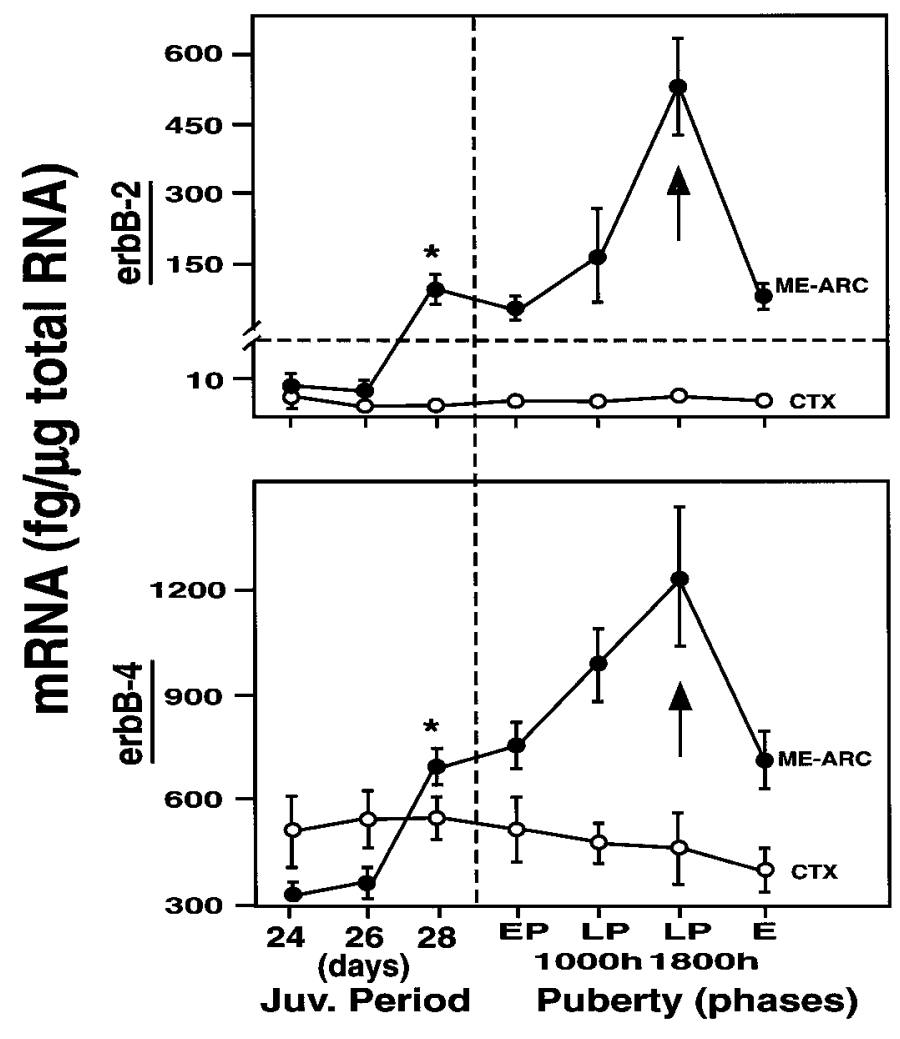

Figure 6. Developmental changes in erbB-2 (top) and erbB-4 (bottom) mRNA content in the medial basal hypothalamus (median eminencearcuate nucleus, ME-ARC region) during juvenile and peripubertal development of the female rat. The increase in gene expression associated with the advent of sexual maturation is contrasted with the lack of changes in the cerebral cortex $(C T X)$, a region of the brain irrelevant to reproductive neuroendocrine control. The dotted vertical line separates the juvenile from the peripubertal periods. EP, Early proestrous phase of puberty; a time during which the first morphological manifestations of puberty become evident as an increase in uterine weight and accumulation of uterine fluid. $L P$, The first proestrus; the first preovulatory discharge of gonadotropins (arrows) takes place in the afternoon of this day. $E$, The first estrus; ovulation occurs in the early morning hours of this day. Each point represents the mean \pm SEM mRNA values (vertical lines) of three independent observations. Each observation derives from hypothalamic tissue pooled from three rats. ${ }^{*} p<0.05$, first significant increase over early (24-d-old) juvenile values.

Table 1. Serum levels of sex steroid in juvenile female rats at the time when hypothalamic erbB-2 and erbB- 4 mRNA content first increases before puberty

\begin{tabular}{lccc} 
& \multicolumn{1}{c}{ Age (days) } & & \\
\cline { 2 - 4 } Steroid & $24(n=10)$ & $26(n=10)$ & $28(n=10)$ \\
\hline $\begin{array}{l}\text { Estradiol }(\mathrm{pg} / \mathrm{ml}) \\
\begin{array}{l}\text { Progesterone } \\
(\mathrm{ng} / \mathrm{ml})\end{array}\end{array}$ & $5.5 \pm 0.34$ & $3.4 \pm 0.27$ & $4.0 \pm 0.21$ \\
$\begin{array}{c}\text { Androstenedione } \\
(\mathrm{pg} / \mathrm{ml})\end{array}$ & $1.39 \pm 0.42$ & $0.94 \pm 0.35$ & $1.98 \pm 0.38$ \\
& $37.7 \pm 5.7$ & $20.0 \pm 0.2$ & $23.0 \pm 3.4$ \\
\hline
\end{tabular}

mediating neurotransmitter-induced LHRH secretion from the hypothalamus (Ojeda et al., 1986b). To determine whether NRG-1 exerts a similar stimulatory effect, cultured hypothalamic astrocytes were treated with three different isoforms of NDF, including NDF- $\beta 1, \beta 2$, and $\alpha 2$ (Wen et al., 1994). These isoforms
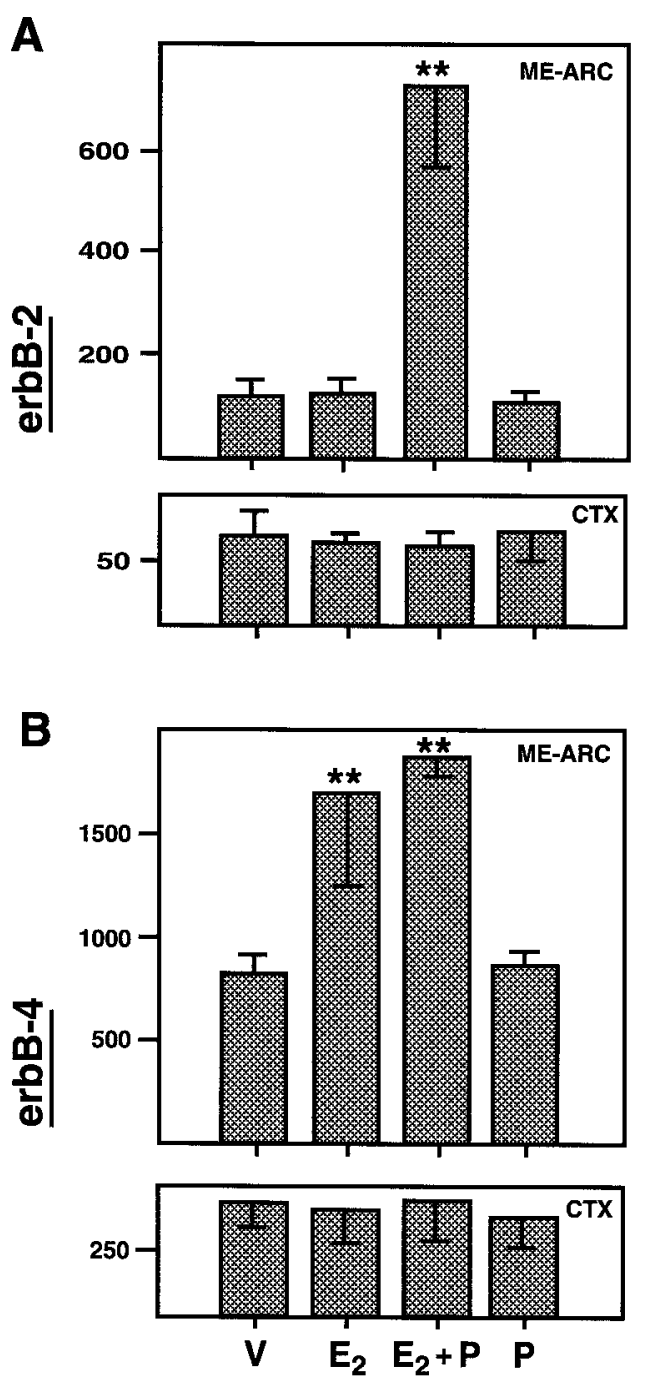

Figure 7. Increase in steady-state levels of erbB-2 and erbB-4 mRNA in the medial basal hypothalamus (ME-ARC region) of juvenile ovariectomized rats induced by $E_{2}$ or the sequential combination of $E_{2}$ plus $P$. The animals were ovariectomized on postnatal day 22 and received $5 \mathrm{~d}$ later a subcutaneous SILASTIC capsule containing $17 \beta-\mathrm{E}_{2}$ at a concentration that produces preovulatory levels of serum $\mathrm{E}_{2}$. Control animals received a capsule filled with the vehicle ( $V$, corn oil). $\mathrm{P}$ was administered $50 \mathrm{hr}$ later (at 12:00 P.M.) as a single subcutaneous injection. All animals were euthanized $4 \mathrm{hr}$ after the $\mathrm{P}$ injection (i.e., at 4:00 P..M., $54 \mathrm{hr}$ after receiving the $\mathrm{E}_{2}$-containing capsule). Each bar represents the mean \pm SEM of three independent observations (vertical lines). Each observation derives from hypothalamic tissue pooled from three rats. ${ }^{*} p<0.01$ versus $\mathrm{V}$-treated group. CTX, Cerebral cortex.

were selected because of their proven ability to promote glial cell function. Thus, the $\beta 1$ and $\alpha 2$ forms induce astrocyte maturation (Pinkas-Kramarski et al., 1994), and the $\beta 2$ form facilitates the survival and maturation of glial cell precursors (Dong et al., 1995). Figure 10 (left) shows that NDF- $\beta 2$ and NDF- $\alpha 2$ were as effective as TGF $\alpha$ in stimulating $\mathrm{PGE}_{2}$ release. Surprisingly, NDF- $\beta 1$, the reported major neuronal NDF isoform (Wen et al., 1994), was ineffective (Fig. 10, left).

\section{Neuregulins facilitate the stimulatory effect of TGF $\alpha$ on PGE2 release from hypothalamic astrocytes}

Because neuregulins bind only to erbB-3 and erbB-4 receptors but recruit erbB-2 and erbB-1 receptors for expanded signal 


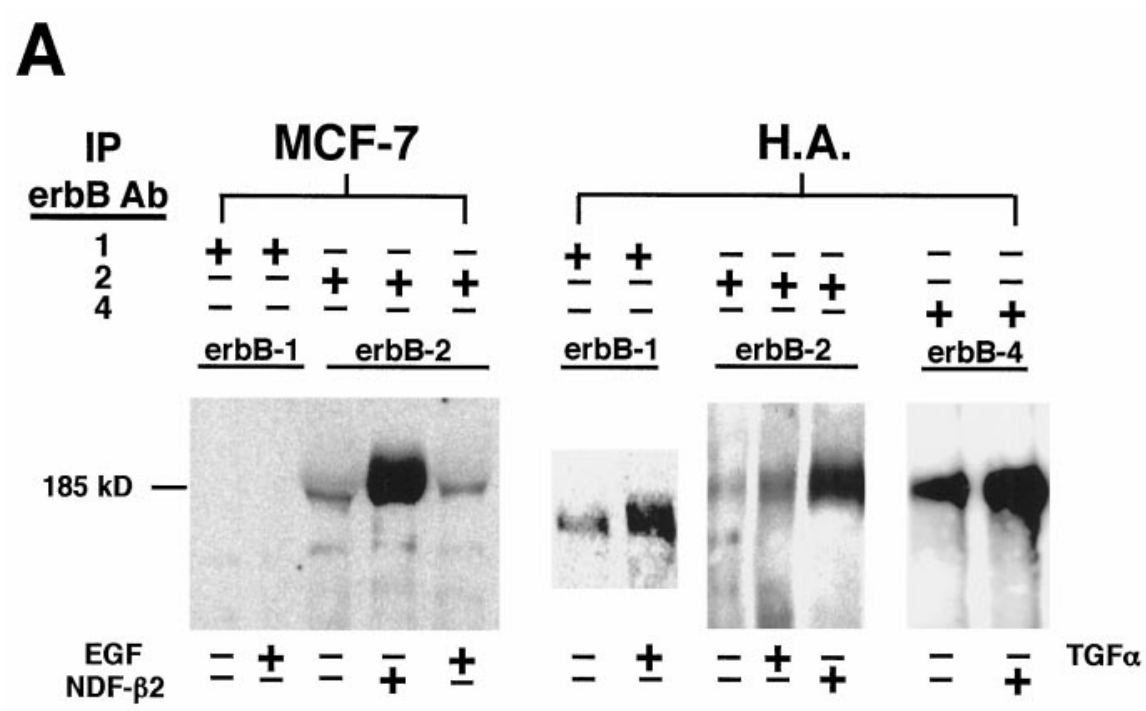

Figure 8. A, Left to right, Tyrosine phosphorylation of erbB-1 and erbB-2 receptors in MCF-7 cells induced by EGF and NDF- $\beta 2$, and phosphorylation of erbB1, erbB-2, and erbB-4 receptors in hypothalamic astrocytes (H.A.) induced by TGF $\alpha$ or NDF- $\beta 2$. The cells were exposed for $5 \mathrm{~min}$ to each ligand (100 $\mathrm{ng} / \mathrm{ml}$ ) before lysis. The erbB receptors were immunoprecipitated $(I P)$ with antibodies specific to each protein, and the tyrosine phosphorylated receptors were identified by Western blots using phosphotyrosine antibodies. B, Left to right, Phosphorylation of erbB-1 and transphosphorylation of erbB-2 in cerebrocortical astrocytes (C.A.) by $\mathrm{TGF} \alpha$; inability of NDF- $\beta_{2}$ to phosphorylate erbB-2 in cortical astrocytes; phosphorylation of erbB-2 in hypothalamic astrocytes by NDF- $\beta 2$; and effectiveness of NDF- $\beta 2$ to induce erbB-2 phosphorylation in cortical astrocytes after transient overexpression (Transf.) of erbB-4.
B

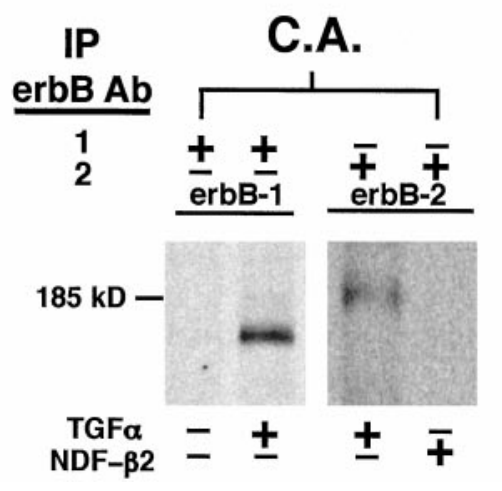

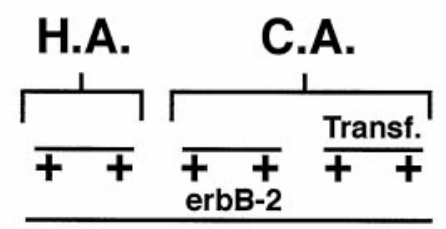

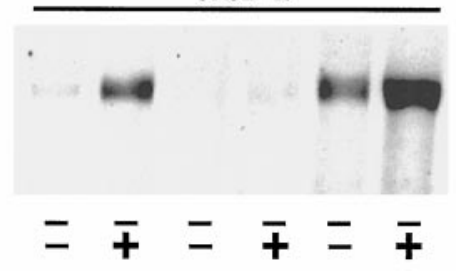

transduction (Beerli et al., 1995; Karunagaran et al., 1996; Lemke, 1996; Burden and Yarden, 1997), we sought to determine whether neuregulins would be able to potentiate the effect of low concentrations of TGF $\alpha$ on glial $\mathrm{PGE}_{2}$ release. Exposure of hypothalamic astrocytes to a low, ineffective dose of NDF- $\beta 2(10 \mathrm{ng} / \mathrm{ml})$ markedly facilitated the effect of marginally effective doses of TGF $\alpha$ (Fig. 10, right), suggesting that the two peptides are required for full erbB receptor-dependent activation of eicosanoid synthesis in hypothalamic astrocytes.

\section{Neuregulin-induced activation of glial $\mathrm{PGE}_{2}$ release requires erbB-2 receptors}

In a variety of cell types, erbB-2 is required for neuregulindependent signaling via erbB-4 receptor activation (Carraway and Cantley, 1994; Beerli et al., 1995). ErbB-2 also functions, via receptor-receptor interactions, as an auxiliary subunit in erbB-1mediated signal transduction (Karunagaran et al., 1996). It was, therefore, important to determine whether targeted inactivation of erbB-2 receptors would affect NRG and/or TGF $\alpha$ signaling capacity in hypothalamic astrocytes, as assessed by the ability of these growth factors to stimulate glial $\mathrm{PGE}_{2}$ release in erbB-2deficient cells. Because inactivation of erbB-2 receptors can be efficiently achieved by either administration of antisense ODNs (Colomer et al., 1994) or the intracellular expression of a recombinant single-chain antibody (Berrli et al., 1994; Beerli et al., 1995), we chose one of these approaches for our studies. Figure 11 (top left) demonstrates the effectiveness of an erbB-2 ODN treatment (1 $\mu \mathrm{M}$ for $16 \mathrm{hr}$ ) to reduce the levels of phosphorylated erbB-2 in hypothalamic astrocytes exposed to a 5 min NDF- $\beta 2$ pulse. The inhibitory effect of the erbB-2 ODN was not seen when the cells were treated with an oligodeoxynucleotide containing the same base composition but in a scrambled order. No effect of the erbB-2 ODN on phosphorylated erbB-4 content was observed (Fig. 11, top right), indicating that the ODN selectively targets erbB-2. NDF- $\beta 2$-induced $\mathrm{PGE}_{2}$ release from hypothalamic astrocytes was abolished by exposing the cells to the same dose of erbB-2 ODN for the duration (16 hr) of the NRG treatment (Fig. 11 , middle). The scrambled sequence was ineffective. The ODN partially blocked the effect of TGF $\alpha$, further indicating that, as in immortalized cell lines (Beerli et al., 1995), erbB-2 is required for full expression of ligand-initiated, erbB-1-dependent signaling in primary astrocytes. The specificity of the erbB-2 ODN effect was further demonstrated by its failure to alter the stimulatory effect of basic FGF, or the lack of effect of IGF-I, on $\mathrm{PGE}_{2}$ release (Fig. 11 , middle). Thus, its inhibitory effect on NRG and TGF $\alpha$ signaling is not a result of a general inactivation of receptor tyrosine kinases in glial cells.

\section{Neuregulins induce LHRH release via a glial intermediacy}

Direct exposure of the LHRH-producing GT1-1 cells to NDF- $\beta 2$ failed to stimulate LHRH release (Fig. 11, bottom). In contrast, 


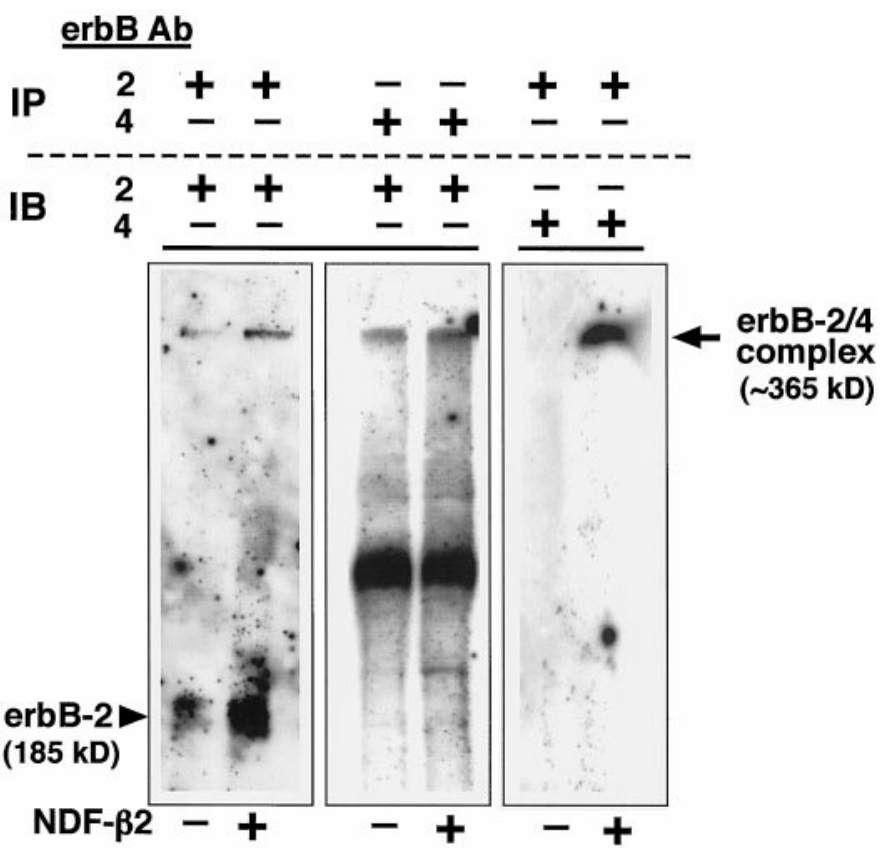

Figure 9. Heterodimerization of erbB-4 with erbB-2 receptors in hypothalamic astrocytes. After exposure to NDF- $\beta 2(500 \mathrm{ng} / \mathrm{ml}, 3 \mathrm{~min})$, the cells were exposed to the cross-linker $\mathrm{BS}^{3}$, lysed, immunoprecipitated $(I P)$ with either erbB-2 or erbB-4 antibodies, and blotted $(I B)$ with erbB-2 or erbB-4 antibodies. Notice the formation of a high molecular weight complex containing both erbB-2 (left and middle) and erbB-4 (right).

the culture medium of hypothalamic astrocytes treated with NDF- $\beta 2$ (N-CM) increased the release of LHRH more than threefold over control values. The changes observed were similar to those induced by the culture medium of astrocytes treated with TGF $\alpha$ (T-CM) (Fig. 11, bottom), a conditioned medium previously shown to stimulate LHRH secretion via its $\mathrm{PGE}_{2}$ content (Ma et al., 1997a). Concomitant treatment of the astrocytes with either NDF- $\beta 2$ or TGF $\alpha$ and the erbB-2 ODN abolished the effect of the NDF- $\beta 2$-conditioned medium on LHRH release and partially suppressed that of the TGF $\alpha$-conditioned medium (Fig. 11 , bottom). Culture medium from astrocytes treated with either NDF- $\beta 2$ or TGF $\alpha$ in the presence of the scrambled erbB-2 ODN sequence was as effective in stimulating LHRH release as culture medium from astrocytes treated with the growth factors alone. Direct application of culture medium from astrocytes treated with the scrambled sequence to GT1-1 cells also failed to affect basal LHRH release (Fig. 11, bottom). Thus, neuregulins appear to stimulate the secretory activity of LHRH-producing neurons via an astroglial-dependent, erbB-mediated activation of $\mathrm{PGE}_{2}$ synthesis.

\section{In vivo disruption of erbB-2 receptor synthesis by central administration of an erbB-2 ODN delays the onset of female puberty}

To determine the physiological importance of hypothalamic erbB-2 receptor signaling in the central control of sexual maturation, juvenile female rats were treated with the same erbB-2 ODN used in the in vitro studies. The ODN was administered into the third ventricle of the brain via a cannula connected to a subcutaneously implanted osmotic minipump, delivering its content at a rate of $2.5 \mu \mathrm{g} / \mathrm{hr}$. The ODN infusion was initiated on postnatal day 25 , i.e., before the first increase in hypothalamic erbB-2 mRNA expression that occurs between postnatal day 26 and 28. Control animals received an infusion of the scrambled ODN or were left intact.

Both control groups reached puberty at a very similar age (Fig. 12), so that by postnatal day 37 all of them had ovulated (mean age at first ovulation, $35.5 \pm 0.27$ and $36.0 \pm 0.30 \mathrm{~d}$ for intact and scrambled ODN-treated groups, respectively). In striking contrast, the animals infused with the erbB-2 ODN did not ovulate until after the content of the pump was exhausted (i.e., after $14 \mathrm{~d}$ of infusion) (Fig. 12). Ovulation occurred within 1-4 d after termination of the infusion, so that the mean age at first ovulation was $41.6 \pm 0.43 \mathrm{~d}$ ( $p<0.01$ vs both control groups). Although these results indicate that erbB-2 receptors, and thus NRGinitiated signaling, is important for the timely initiation of female reproductive capacity, they also demonstrate that the central regulatory component that controls the onset of puberty can fully, and expeditiously, recover from the inhibitory effect of the erbB-2 ODN upon termination of the treatment.

\section{DISCUSSION}

In keeping with previous observations demonstrating that astroglial cells are targets of NRG action (Pinkas-Kramarski et al., 1994; Rio et al., 1997), our findings show that hypothalamic astrocytes contain functional NRG receptors of the erbB-2erbB-4 subtypes. Ligand-dependent activation of this erbB-2erbB-4 complex leads to the formation of substances involved in facilitating release of LHRH. Disruption of the complex abolishes the astrocytic response to NRGs and delays the onset of puberty when effected in vivo. Thus, regardless of any direct effect of NRGs on hypothalamic neurons, our findings indicate that astrocytic erbB-2-erbB-4 receptors are intrinsic components of the cell-cell signaling process that underlies the initiation of female puberty.

Although in several other cellular systems, NRGs use erbB-3 receptors to affect cellular function (Carraway and Cantley, 1994; Lemke, 1996; Burden and Yarden, 1997), neither the hypothalamus as a whole nor isolated hypothalamic astrocytes express the erbB-3 gene. Surprisingly, erbB-4 receptors found in hypothalamic astrocytes were not detected in astrocytes of the cerebral cortex, a region of the brain irrelevant to neuroendocrine control. Thus, as previously shown for the autoregulatory control of $\mathrm{TGF} \alpha$ gene expression and the expression of estrogen receptors (Ma et al., 1994a), hypothalamic astrocytes appear to be molecularly different from astrocytes of brain regions not involved in neuroendocrine regulation.

The essential role of erbB-4 in mediating the effects of NRGs on hypothalamic astrocytes is indicated by three findings: (1) NRG1promotes heterodimerization of erbB-4 and erbB-2 in hypothalamic astrocytes, (2) NRG1 induces phosphorylation of erbB-2 in hypothalamic astrocytes (which contain erbB-4) but not cortical astrocytes (which lack these receptors), and (3) cortical astrocytes respond to NRG1 with erbB-2 phosphorylation only after gene transfer-mediated expression of erbB-4 receptors. That a normal contingent of functional erbB-4 receptors in astroglial cells is important for normal neuroendocrine reproductive development is suggested by the decreased plasma follicle-stimulating hormone levels observed in transgenic mice expressing an erbB-4 dominant negative mutant gene in astroglial cells (V. Prevot, C. Rio, Y. J. Ma, W. L. Dees, S. R. Ojeda, and G. Corfas, unpublished observations).

Earlier observations have led to the concept that $\mathrm{TGF} \alpha$ is a physiological component of the glia-to-neuron signaling process that regulates $\mathrm{LHRH}$ neuronal activity during sexual develop- 
Figure 10. Left, Stimulatory effect of neuregulin isoforms (each at $50 \mathrm{ng} / \mathrm{ml}$ ) on $\mathrm{PGE}_{2}$ release from cultured hypothalamic astrocytes and comparison with the effect of TGF $\alpha(50 \mathrm{ng} / \mathrm{ml})$. Right, Potentiation of the effect of TGF $\alpha$ on $\mathrm{PGE}_{2}$ release from hypothalamic astrocytes by a dose of NDF- $\beta 2(10 \mathrm{ng} / \mathrm{ml})$ that by itself is ineffective. Bars or circles represent the mean of five to nine culture wells per group. Vertical lines are SEM. ${ }^{*} p<0.01$ versus control $(C)$ group.
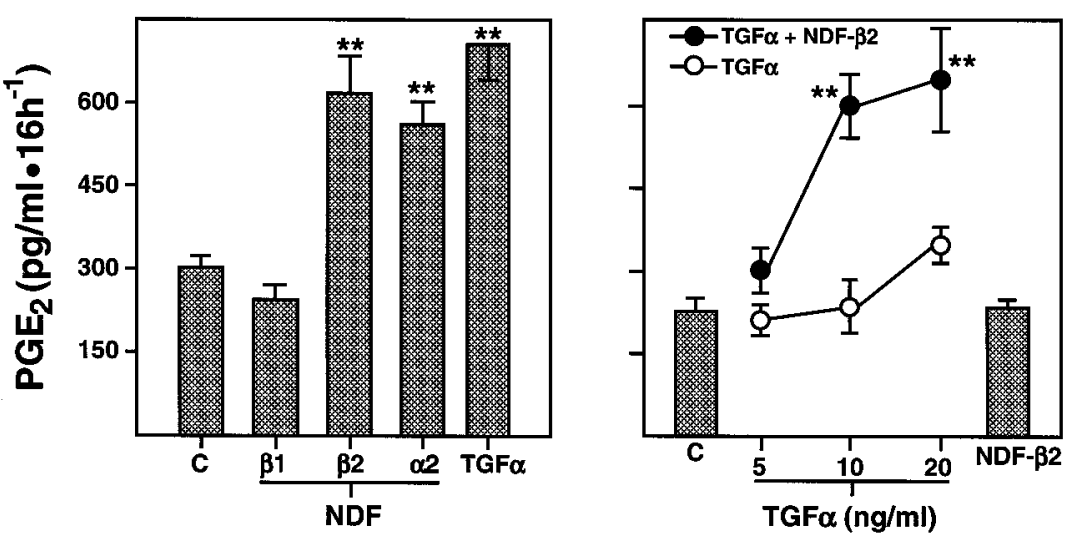

ment (Ma et al., 1992; Ojeda, 1994). The present findings indicate that actions of NRGs in hypothalamic astrocytes are closely coordinated with those of TGF $\alpha$. On the one hand, and as shown in cell lines (King et al., 1988; Goldman et al., 1990; Wada et al., 1990; Riese et al., 1996), TGF $\alpha$ shares with NRG-1 the ability to induce phosphorylation of erbB-2. On the other, both growth factors can act independently on cultured astrocytes to stimulate release of $\mathrm{PGE}_{2}$; when given together at ineffective doses, their individual effects are potentiated. Disruption of erbB-2 synthesis via an antisense oligodeoxynucleotide approach abolished the effect of $\mathrm{NRG} 1$ on $\mathrm{PGE}_{2}$ release and reduced that of $\mathrm{TGF} \alpha$, implying that the recruitment of erbB- 2 by activation of erbB-1 and erbB-4 receptors activates at least one common intracellular signal transduction pathway leading to eicosanoid formation. Although transduction of erbB-1-mediated signaling has been shown to involve metabolism of arachidonic acid to oxygenated products (Takasu et al., 1987), the pathways that may lead to prostaglandin formation upon erbB-2-erbB-4 receptor activation are not known.

The initiation of puberty is thought to be determined by events that occur within the brain independently of changes in gonadal steroid output (Ojeda and Urbanski, 1994; Terasawa, 1995). Once the change in "central drive" is initiated, the attendant changes in the secretion of pituitary gonadotropin hormones lead to activation of gonadal hormone secretion. Ovarian estrogen, in particular, becomes a prominent player in the process, because it not only promotes maturation of the reproductive organs but also facilitates further neuroendocrine development and, eventually, triggers the first preovulatory surge of gonadotropins. The present findings show that the hypothalamic content of the mRNAs encoding both erbB- 2 and erbB-4 increases in two stages: first, during juvenile days, in the face of unchanging plasma steroid levels, and then at the time of puberty when ovarian steroid secretion is elevated. This latter increase in erbB receptor expression was reproduced by mimicking in immature rats the changes in circulating estrogen and progesterone levels seen at the time of puberty. It is thus likely that the earlier activation of hypothalamic erbB-2-erbB-4 gene expression is part of the gonad-independent increase in central drive that initiates puberty, whereas the subsequent, peripubertal increase is a steroiddependent phenomenon. We do not know, however, whether these changes in erbB mRNA abundance are because of more cells expressing the receptors or a greater density of receptors per cell.

The existence of a functional relationship between the erbB signaling network and estrogen was initially recognized by the demonstration that estrogen can acutely upregulate the level of erbB-1 in uterus (Mukku and Stancel, 1985). More recently, the two systems were shown to be linked by cross talk mechanisms involving the transcriptional activation of estrogen responsive elements by both EGF and TGF $\alpha$ (Ignar-Trowbridge et al., 1993), the direct activation of erbB-2 phosphorylation by estrogen binding to the erbB-2 extracellular domain (Matsuda et al., 1993), and the mediatory contribution of the estrogen receptor to erbB-1 receptor signaling (Curtis et al., 1996). Earlier work demonstrated that estrogen increases TGF $\alpha$ gene expression in hypothalamic astrocytes (Ma et al., 1994a). The present findings extend these observations to include two more members of the erbB signaling network, erbB-2 and erbB-4, as targets of estrogen action. It is possible that activation of the hypothalamic erbB-2erbB-4 complex before any increase in estrogen secretion occurs sets in motion signaling pathways specific to the NRG-erbB network and estrogen-dependent events able to accelerate the tempo of the pubertal process. During the onset of puberty itself the actions of estrogen may be potentiated by an increased activation of the erbB signaling module. Such an interaction has been demonstrated by the inability of EGF to exert estrogen-like effects in mice carrying a null mutation of the estrogen receptor (Curtis et al., 1996).

The present study does not identify the NRGs physiologically responsible for the prepubertal activation of the hypothalamic erbB-2-erbB-4 complex. To date, three subfamilies of NRGs have been identified. Members of the original family, now termed NRG1, consist of alternatively spliced products of a single gene (Marchionni et al., 1993; Wen et al., 1994). The second group, known as NRG2, is comprised of two members, NRG2 $\alpha$ and NRG2 $\beta$, which are encoded by a gene different from that encoding NRG1 (Carraway et al., 1997; Chang et al., 1997). An additional NRG, termed NRG3, is preferentially expressed in nervous tissue (Zhang et al., 1997). Our study shows that only NRG1 and NRG3 are produced in the hypothalamus as a whole and in astrocytes in particular. Thus, both of them may serve as physiological ligands for the astrocytic erbB-2-erbB-4 complex.

Several studies have demonstrated the importance of erbB-2 in erbB receptor-mediated signaling. ErbB-2 enhances the binding affinities of EGF to erbB-1 and NRGs to erbB-3 and erbB-4 via deceleration of ligand dissociation rates (Karunagaran et al., 1996). Although in some cellular contexts erbB- 2 is not required for NRG action (Beerli et al., 1995), heterodimeric receptor complexes that include erbB-2 have a greater affinity for NRGs than those complexes not containing erbB-2 (Tzahar et al., 1997). Moreover, NRGs appear to prefer the recruitment of erbB-2 for 

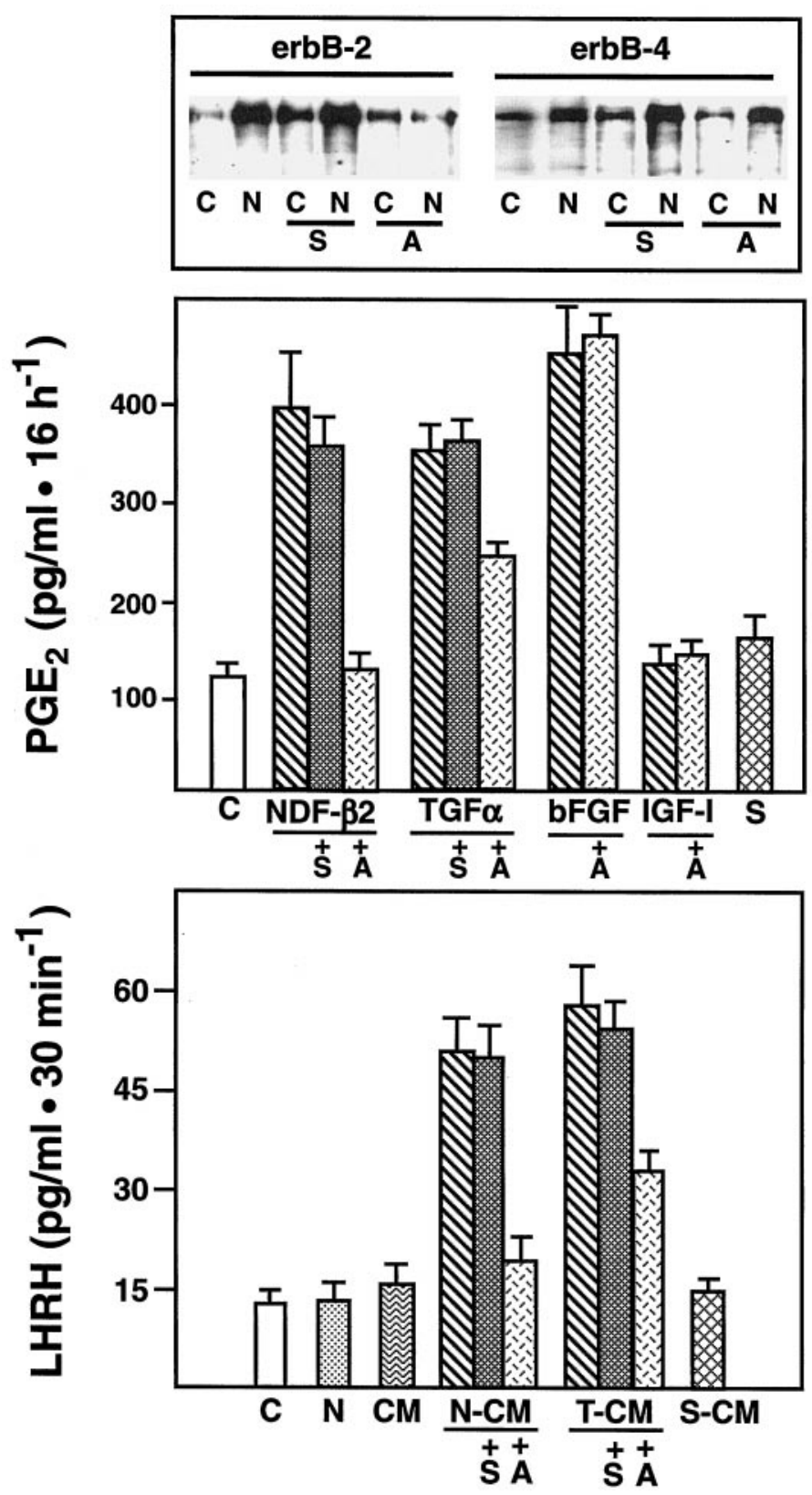

Figure 11. Top left, Selective decrease of phosphorylated erbB-2 in hypothalamic astrocytes treated with an antisense oligodeoxynucleotide to erbB-2 (erbB-2 ODN). The cells were treated with the ODN $(A, 1 \mu \mathrm{M})$ or a scrambled sequence $(S)$ for $16 \mathrm{hr}$. Then, some dishes were left untreated $(C)$ and others were exposed to NDF- $\beta 2(N, 50 \mathrm{ng} / \mathrm{ml})$ for 5 min before immunoprecipitation and electrophoretic separation of phosphorylated erbB receptors. The phosphorylated receptors were detected with an antiphosphotyrosine monoclonal antibody. Top right, Failure of erbB-2 ODN to alter NDF- $\beta 2$-induced erbB-4 receptor phosphorylation. Middle, Blockade of the stimulatory effect of NDF- $\beta 2$ and partial inhibition of the effect of TGF $\alpha$ on $\mathrm{PGE}_{2}$ release from cultured hypothalamic astrocytes by ODN-mediated inhibition of erbB-2 synthesis. Each growth factor was tested at $50 \mathrm{ng} / \mathrm{ml}$; the erbB-2 ODN was used at a $1 \mu \mathrm{M}$ concentration. $b F G F$, Basic fibroblast growth factor, $50 \mathrm{ng} / \mathrm{ml} ; I G F-I$, insulin-like growth factor I, $50 \mathrm{ng} / \mathrm{ml} ; C$, untreated controls; $A$, erbB-2 ODN; $S$, scrambled erbB-2 ODN sequence. Bottom, Stimulatory effect of a culture medium conditioned by exposure of hypothalamic astrocytes to NDF- $\beta 2$ or TGF $\alpha$ on LHRH release from the GT1-1 LHRH-producing cells and blockade of this effect by treating the astrocytes with an erbB-2 ODN. $N$, GT1-1 cells treated directly with NDF- $\beta 2(50 \mathrm{ng} / \mathrm{ml}) ; C M$, cells treated with the conditioned medium from astrocytes cultured in the absence of added growth factors; $N-C M$, astrocyte culture medium con-

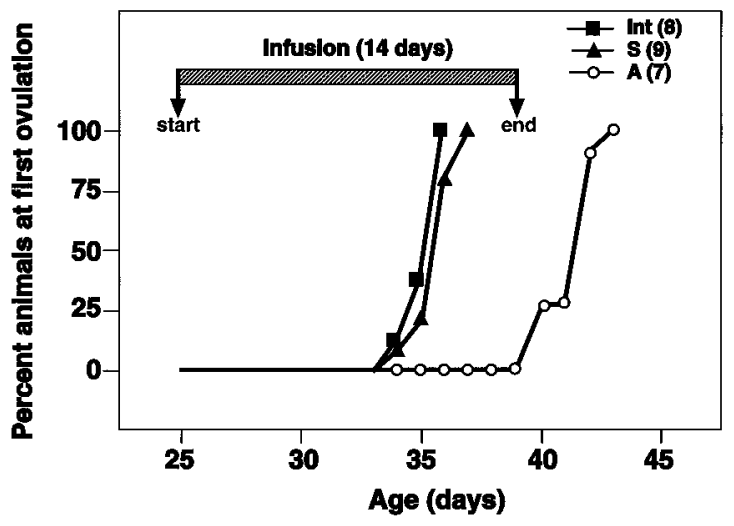

Figure 12. Delay of female puberty by targeted disruption of erbB-2 receptor synthesis via central administration of an erbB-2 ODN to developing rats. The erbB-ODN $(A)$ or its scrambled sequence $(S)$ were infused into the third ventricle of the brain via a stainless steel cannula connected to a subcutaneously implanted Alzet minipump delivering its content at the rate of $0.5 \mu \mathrm{l} / \mathrm{hr}$ for $14 \mathrm{~d}$. The amount of ODN delivered was of $2.5 \mu \mathrm{g} / \mathrm{hr}$. Numbers in parentheses are number of animals per group.

the formation of ligand-driven heterodimeric receptors (Tzahar et al., 1997), indicating that, in cells expressing erbB-2 and erbB-4 receptors, such as hypothalamic astrocytes, recruitment of erbB-2 to form a heterodimeric complex may be the preferred mechanism used by NGRs to achieve high-affinity binding and activation of effector signaling pathways.

The importance of erbB-2 for the initiation of puberty is suggested by the delay in puberty caused by the central inactivation of erbB-2 receptors via administration of an antisense ODN. That this delay was not caused by a toxic effect of the ODN is indicated by the normal growth of the animals during treatment and by the rapid initiation of reproductive development after termination of the ODN infusion. The ODN tested in vitro selectively reduced ligand-dependent erbB-2 phosphorylation without affecting that of erbB-4 and blocked the stimulatory action of NRG1 on astrocytic release of $\mathrm{PGE}_{2}$, without affecting that of bFGF, which also acts via a receptor tyrosine kinase. An intact bFGF signaling system did not appear to compensate in vivo for the deficiency in erbB-2-dependent signaling during puberty (this study) or during early nervous system development (Morris et al., 1999).

Together, the present results indicate that NRG-mediated activation of an erbB signaling module composed of erbB-2 and erbB-4 receptors is an important component of the glia-to-neuron communication system controlling the secretory activity of LHRH neurons. Activation of this receptor complex appears to be involved in both the initial gonad-independent events that set in motion the pubertal process and the progression of steroidregulated changes leading to the completion of puberty. The results are consistent with a model in which LHRH secretion is stimulated via a two-step mechanism. The initial step would involve a juxtacrine-paracrine stimulation of erbB receptors in astroglial cells via cell contact-dependent signaling (Fagotto and

$\leftarrow$

ditioned by treating the astrocytes with NDF- $\beta 2(50 \mathrm{ng} / \mathrm{ml})$ for $16 \mathrm{hr}$; $T$-CM, astrocyte culture medium conditioned by TGF $\alpha$ treatment (50 $\mathrm{ng} / \mathrm{ml}, 16 \mathrm{hr}) ; S-C M$, culture medium conditioned by treating the astrocytes with the scrambled ODN sequence. Bars are mean of six wells per group; vertical lines are SEM. 
Gumbiner, 1996). The second would involve release of neuroactive substances, such as $\mathrm{PGE}_{2}$, capable of inducing the secretory activity of neighboring LHRH neurons. This mechanism is not exclusive to NRGs, because it also appears to operate in the case of the TGF $\alpha$-erbB-1 signaling complex (Ojeda, 1994). The requirement of erbB-2 for both signaling processes strongly suggests that the activation of these two systems is a highly coordinated and interactive process involved in controlling the onset of mammalian puberty.

\section{REFERENCES}

Akiyama T, Saito T, Ogawara H, Toyoshima K, Yamamoto T (1988) Tumor promoter and epidermal growth factor stimulate phosphorylation of the c-erbB-2 gene product in MKN-7 human adenocarcinoma cells. Mol Cell Biol 8:1019-1026.

Andrews WW, Advis JP, Ojeda SR (1980) The first proestrus in the female rat: Circulating steroid levels preceding and accompanying the preovulatory LH surge. Proc Soc Exp Biol Med 163:305-309.

Andrews WW, Mizejewski GJ, Ojeda SR (1981) Development of estradiol-positive feedback on luteinizing hormone release in the female rat: a quantitative study. Endocrinology 109:1404-1413.

Bargmann CI, Hung M-C, Weinberg RA (1986a) Multiple independent activations of the neu oncogene by a point mutation altering the transmembrane domain of p185. Cell 45:649-657.

Bargmann CI, Hung MC, Weinberg RA (1986b) The neu oncogene encodes an epidermal growth factor receptor-related protein. Nature 319:226-230.

Beerli RR, Graus-Porta D, Woods-Cook K, Chen X, Yarden Y, Hynes NE (1995) Neu differentiation factor activation of ErbB-3 and ErbB-4 is cell specific and displays a differential requirement for ErbB-2. Mol Cell Biol 15:6496-6505.

Berg-von der Emde K, Dees WL, Hiney JK, Hill DF, Dissen GA, Costa ME, Moholt-Siebert M, Ojeda SR (1995) Neurotrophins and the neuroendocrine brain: different neurotrophins sustain anatomically and functionally segregated subsets of hypothalamic dopaminergic neurons. J Neurosci 15:4223-4237.

Berrli RR, Wels W, Hynes NE (1994) Intracellular expression of single chain antibodies reverts ErbB-2 transformation. J Biol Chem 269:23931-23936.

Brann DW, Mahesh VB (1994) Excitatory amino acids: function and significance in reproduction and neuroendocrine regulation. Front Neuroendocrinol 15:3-49.

Burden S, Yarden Y (1997) Neuregulins and their receptors: a versatile signaling module in organogenesis and oncogenesis. Neuron 18:847-855.

Campbell WB, Ojeda SR (1987) Measurement of prostaglandins by radioimmunoassay. Methods Enzymol 141:323-350.

Carpenter G, Cohen S (1990) Epidermal growth factor. J Biol Chem 265:7709-7712.

Carraway KL, Cantley LC (1994) A neu acquaintance for ErbB3 and ErbB4: a role for receptor heterodimerization in growth signaling. Cell 78:5-8.

Carraway KL, Weber JL, Unger MJ, Ledesma J, Yu N, Gassmann M, Lai C (1997) Neuregulin-2, a new ligand of ErbB3/ErbB4-receptor tyrosine kinases. Nature 387:512-516.

Chang H, Riese DJ, Gilbert W, Stern DF, McMahan UJ (1997) Ligands for ErbB-family receptors encoded by a neuregulin-like gene. Nature 387:509-516.

Cohen BD, Green JM, Foy L, Fell HP (1996) HER4-mediated biological and biochemical properties in NIH $3 \mathrm{T3}$ cells. J Biol Chem 271:4813-4818.

Colomer R, Lupu R, Bacus SS, Gelmann EP (1994) erbB-2 antisense oligonucleotides inhibit the proliferation of breast carcinoma cells with erbB-2 oncogene amplification. Br J Cancer 70:819-825.

Correa-Rotter R, Mariash CN, Rosenberg ME (1992) Loading and transfer control for Northern hybridization. BioTechniques 12:154-158.

Crowley WR, Parker SL, Sahu A, Kalra SP (1995) Interacting transmembrane signals regulating GnRH and LH secretion. In: The neurobiology of puberty (Plant TM, Lee PA, eds), pp 41-54. Bristol, UK: Journal of Endocrinology.

Curtis SW, Washburn T, Sewall C, DiAugustine R, Lindzey J, Couse JF,
Korach KS (1996) Physiological coupling of growth factor and steroid receptor signaling pathways: estrogen receptor knockout mice lack estrogen-like response to epidermal growth factor. Proc Natl Acad Sci USA 93:12626-12630.

Dalva MB, Katz LC (1994) Rearrangements of synaptic connections in visual cortex revealed by laser photostimulation. Science 265:255-258.

Danielson PE, Forss-Petter S, Brow MA, Calavetta L, Douglass J, Milner RJ, Sutcliffe JG (1988) p1B15: a cDNA clone of the rat mRNA encoding cyclophilin. DNA 7:261-267.

Dong Z, Brennan A, Liu N, Yarden Y, Lefkowitz G, Mirsky R, Jessen KR (1995) Neu differentiation factor is a neuron-glial signal and regulates survival, proliferation, and maturation of rat Schwann cell precursors. Neuron 15:585-596.

Fagotto F, Gumbiner BM (1996) Cell contact-dependent signaling. Dev Biol 180:445-454.

Gallo F, Morale MC, Avola R, Marchetti B (1995) Cross-talk between luteinizing hormone-releasing hormone ( $\mathrm{LHRH})$ neurons and astroglial cells: developing glia release factors that accelerate neuronal differentiation and stimulate LHRH release from $\mathrm{GT}_{1-1}$ neuronal cell line and LHRH neurons induce astroglia proliferation. Endocrine 3:863-874.

Goldman R, Ben Levy R, Peles E, Yarden Y (1990) Heterodimerization of the erbB-1 and erbB-2 receptors in human breast carcinoma cells: a mechanism for receptor transregulation. Biochemistry 29:11024-11028.

Ignar-Trowbridge DM, Teng CT, Ross KA, Parker MG, Korach KS, McLachlan JA (1993) Peptide growth factors elicit estrogen receptordependent transcriptional activation of an estrogen-responsive element. Mol Endocrinol 7:992-998.

Jung H, Shannon EM, Fritschy J-M, Ojeda SR (1997) Several GABA receptor subunits are expressed in LHRH neurons of juvenile female rats. Brain Res 780:218-229.

Karunagaran D, Tsahar E, Beerli RR, Chen X, Graus-Porta D, Ratzkin BJ, Seger R, Hynes NE, Yarden Y (1996) ErbB-2 is a common auxiliary subunit of NDF and EGF receptors: implications for breast cancer. EMBO J 15:254-264.

King CR, Borrello I, Bellot F, Comoglio P, Schlessinger J (1988) EGF binding to its receptor triggers a rapid tyrosine phosphorylation of the erbB-2 protein in the mammary tumor cell line SK-BR-3. EMBO J 7:1647-1651.

King JC, Letourneau RL (1994) Luteinizing hormone-releasing hormone terminals in the median eminence of rats undergo dramatic changes after gonadectomy, as revealed by electron microscopic image analysis. Endocrinology 134:1340-1351.

Kraus MH, Issing W, Miki T, Popescu NC, Aaronson SA (1989) Isolation and characterization of ERBB3, a third member of the ERBB/ epidermal growth factor receptor family: evidence for overexpression in a subset of human mammary tumors. Proc Natl Acad Sci USA 86:9193-9197.

Lara HE, Hill DF, Katz KH, Ojeda SR (1990) The gene encoding nerve growth factor is expressed in the immature rat ovary: effect of denervation and hormonal treatment. Endocrinology 126:357-363.

Lemke G (1996) Neuregulins in development. Mol Cell Neurosci 7:247-262.

Ma YJ, Junier M-P, Costa ME, Ojeda SR (1992) Transforming growth factor alpha $(\mathrm{TGF} \alpha)$ gene expression in the hypothalamus is developmentally regulated and linked to sexual maturation. Neuron 9:657-670.

Ma YJ, Berg-von der Emde K, Moholt-Siebert M, Hill DF, Ojeda SR (1994a) Region-specific regulation of transforming growth factor $\alpha$ $(\mathrm{TGF} \alpha)$ gene expression in astrocytes of the neuroendocrine brain. J Neurosci 14:5644-5651.

Ma YJ, Hill DF, Junier M-P, Costa ME, Felder SE, Ojeda SR (1994b) Expression of epidermal growth factor receptor changes in the hypothalamus during the onset of female puberty. Mol Cell Neurosci $5: 246-262$.

Ma YJ, Dissen GA, Rage F, Ojeda SR (1996) RNase protection assay. Methods 10:273-278.

Ma YJ, Berg-von der Emde K, Rage F, Wetsel WC, Ojeda SR (1997a) Hypothalamic astrocytes respond to transforming growth factor alpha with secretion of neuroactive substances that stimulate the release of luteinizing hormone-releasing hormone. Endocrinology 138:19-25.

Ma YJ, Hill DF, Costa ME, Ojeda SR (1997b) Involvement of epidermal growth factor receptor (EGFR) related receptors in the control of female puberty. Soc Neurosci Abstr 23:417.

Marchionni MA, Goodearl ADJ, Chen MS, Bermingham-McDonogh O, Kirk C, Hendricks M, Danehy F, Misumi D, Sudhalter J, Kobayashi K, 
Wroblewski D, Lynch C, Baldassare M, Hiles I, Davis JB, Hsuan JJ, Totty NF, Otsu M, McBurney RN, Waterfield MD, Stroobant P, Gwynne D (1993) Glial growth factors are alternatively spliced erbB2 ligands expressed in the nervous system. Nature 362:312-318.

Massague J (1990) Transforming growth factor- $\alpha$. A model for membrane-anchored growth factors. J Biol Chem 265:21393-21396.

Matsuda S, Kadawaki Y, Ichino M, Akiyama T, Toyoshima K, Yamamoto $\mathrm{T}$ (1993) $17 \beta$-Estradiol mimics ligand activity of the $c$-erbB2 protooncogene product. Proc Natl Acad Sci USA 90:10803-10807.

Mayerhofer A, Dissen GA, Parrott JA, Hill DF, Mayerhofer D, Garfield RE, Costa ME, Skinner MK, Ojeda SR (1996) Involvement of nerve growth factor in the ovulatory cascade: TrkA receptor activation inhibits gap-junctional communication between thecal cells. Endocrinology 137:5662-5670.

Melcangi RC, Galbiati M, Messi E, Piva F, Martini L, Motta M (1995) Type 1 astrocytes influence luteinizing hormone-releasing hormone release from the hypothalamic cell line GT1-1: is transforming growth factor- $\beta$ the principle involved? Endocrinology 136:679-686.

Morris JK, Lin W, Hauser C, Marchuk Y, Getman D, Lee K-F (1999) Rescue of the cardiac defect in erbB2 mutant mice reveals essential roles of erbB2 in peripheral nervous system development. Neuron 23:273-283.

Mukku VR, Stancel GM (1985) Regulation of epidermal growth factor receptor by estrogen. J Biol Chem 260:9820-9824.

Ojeda SR (1994) The neurobiology of mammalian puberty: has the contribution of glial cells been underestimated? J NIH Res 6:51-56.

Ojeda SR, Ma YJ (1995) The role of growth factors in the neuroendocrine control of female sexual development. Curr Opin Endocrinol Diabetes 2:148-156.

Ojeda SR, Urbanski HF (1994) Puberty in the rat. In: The physiology of reproduction, Ed 2, Vol 2 (Knobil E, Neill JD, eds), pp 363-409. New York: Raven.

Ojeda SR, Urbanski HF, Katz KH, Costa ME (1986a) Activation of estradiol positive feedback at puberty: estradiol sensitizes the LHRH releasing system at two different biochemical steps. Neuroendocrinology 43:259-265.

Ojeda SR, Urbanski HF, Katz KH, Costa ME, Conn PM (1986b) Activation of two different but complementary biochemical pathways stimulates release of hypothalamic luteinizing hormone-releasing hormone. Proc Natl Acad Sci USA 83:4932-4936.

Ojeda SR, Hill DF, Katz KH (1991) The genes encoding nerve growth factor and its receptor are expressed in the developing female rat hypothalamus. Mol Brain Res 9:47-55.

Olson BR, Scott DC, Wetsel WC, Elliot SJ, Tomic M, Stojilkovic S, Nieman LK, Wray S (1995) Effects of insulin-like growth factors I and II and insulin on the immortalized hypothalamic GT1-7 cell line. Neuroendocrinology 62:155-165.

Pinkas-Kramarski R, Eilam R, Spiegler O, Lavi S, Liu N, Chang D, Wen D, Schwartz M, Yarden Y (1994) Brain neurons and glial cells express neu differentiation factor/heregulin: a survival factor for astrocytes. Proc Natl Acad Sci USA 91:9387-9391.

Plowman GD, Whitney GS, Neubauer MG, Green JM, McDonald VL, Todaro GJ, Shoyab M (1990) Molecular cloning and expression of an additional epidermal growth factor receptor-related gene. Proc Natl Acad Sci USA 87:4905-4909.

Plowman GD, Culouscou J-M, Whitney GS, Green JM, Carlton GW, Foy L, Neubauer MG, Shoyab M (1993a) Ligand-specific activation of HER4/p180 ${ }^{\text {erbB4}}$, a fourth member of the epidermal growth factor receptor family. Proc Natl Acad Sci USA 90:1746-1750.

Plowman GD, Green JM, Culouscou J-M, Carlton GW, Rothwell VM, Buckley S (1993b) Heregulin induces tyrosine phosphorylation of HER4/-180 ${ }^{\text {erbB4}}$. Nature 366:473-475.

Rage F, Hill DF, Sena-Esteves M, Breakefield XO, Coffey RJ, Costa ME, McCann SM, Ojeda SR (1997) Targeting transforming growth factor $\alpha$ expression to discrete loci of the neuroendocrine brain induces female sexual precocity. Proc Natl Acad Sci USA 94:2735-2740.
Riese DJ, Kim ED, Elenius K, Buckley S, Klagsbrun M, Plowman GD, Stern DF (1996) The epidermal growth factor receptor couples transforming growth factor- $\alpha$ heparin-binding epidermal growth factor-like factor, and amphiregulin to neu, ErbB-3 and ErbB-4. J Biol Chem 271:20047-20052.

Rio C, Rieff HI, Qi P, Corfas G (1997) Neuregulin and erbB receptors play a critical role in neuronal migration. Neuron 19:39-50.

Silverman A-J, Livne I, Witkin JW (1994) The gonadotropin-releasing hormone $(\mathrm{GnRH})$, neuronal systems: immunocytochemistry and in situ hybridization. In: The physiology of reproduction, Ed 2, Vol 1 (Knobil E, Neill JD, eds), pp 1683-1709. New York: Raven.

Simmons DM, Arriza JL, Swanson LW (1989) A complete protocol for in situ hybridization of messenger RNAs in brain and other tissues with radiolabeled single-stranded RNA probes. J Histotechnol 12:169-181.

Spivak-Kroizman T, Rotin D, Pinchasi D, Ullrich A, Schlessinger J, Lax I (1992) Heterodimerization of c-erbB2 with different epidermal growth factor receptor mutants elicits stimulatory or inhibitory responses. J Biol Chem 267:8056-8063.

Staros JV, Kakkad BP (1983) Cross-linking and chymotryptic digestion of the extracytoplasmic domain of the anion exchange channel in intact human erythrocytes. J Membr Biol 74:247-254.

Suen T-C, Hung M-C (1990) Multiple cis- and trans-acting elements involved in regulation of the nеu gene. Mol Cell Biol 10:6306-6315.

Takasu N, Sato S, Yamada T, Shimizu Y (1987) Epidermal growth factor (EGF) and tumor promoter 12-O-tetradecanoylphorbol 13-acetate (TPA) stimulate PG synthesis and thymidine incorporation in cultured porcine thyroid cells. Biochem Biophys Res Commun 143:880-884.

Terasawa E (1995) Mechanisms controlling the onset of puberty in primates: the role of GABAergic neurons. In: The neurobiology of puberty (Plant TM, Lee PA, eds), pp 139-151. Bristol, UK: Journal of Endocrinology.

Tsai P-S, Werner S, Weiner RI (1995) Basic fibroblast growth factor is a neurotropic factor in GT1 gonadotropin-releasing hormone neuronal cell lines. Endocrinology 136:3831-3838.

Tzahar E, Pinkas-Kramarski R, Moyer JD, Klapper LN, Alroy I, Levkowitz G, Shelly M, Henis S, Eisenstein M, Ratzkin BJ, Sela M, Andrews GC, Yarden Y (1997) Bivalence of EGF-like ligands drives the ErbB signaling network. EMBO J 16:4938-4950.

Voigt P, Ma YJ, Gonzalez D, Fahrenbach WH, Wetsel WC, Berg-von der Emde K, Hill DF, Taylor KG, Costa ME, Seidah NG, Ojeda SR (1996) Neural and glial-mediated effects of growth factors acting via tyrosine kinase receptors on LHRH neurons. Endocrinology 137:2593-2605.

Wada T, Qian X, Greene MI (1990) Intermolecular association of the p185 ${ }^{\text {neu }}$ protein and EGF receptor modulates EGF receptor function. Cell 61:1339-1347.

Wen D, Peles E, Cupples R, Suggs SV, Bacus SS, Luo Y, Trail G, Hu S, Silbiger SM, Ben Levy R, Koski RA, Lu HS, Yarden Y (1992) Neu differentiation factor: a transmembrane glycoprotein containing an EGF domain and an immunoglobulin homology unit. Cell 69:559-572.

Wen D, Suggs SV, Karunagaran D, Liu N, Cupples RL, Luo Y, Janssen AM, Ben-Baruch N, Trollinger DB, Jacobsen VL, Meng S-Y, Lu HS, Hu S, Chang D, Yang W, Yanigahara D, Koski RA, Yarden Y (1994) Structural and functional aspects of the multiplicity of neu differentiation factors. Mol Cell Biol 14:1909-1919.

Witkin JW, Ferin M, Popilskis SJ, Silverman A-J (1991) Effects of gonadal steroids on the ultrastructure of GnRH neurons in the rhesus monkey: synaptic input and glial apposition. Endocrinology 129:1083-1092.

Zhang D, Sliwkowski MX, Mark M, Frantz G, Akita R, Sun Y, Hillan K, Crowley C, Brush J, Godowski PJ (1997) Neuregulin-3 (NGR3): a novel neural tissue-enriched protein that binds and activates ErbB4. Proc Natl Acad Sci USA 94:9562-9567.

Zhang K, Sun J, Liu N, Wen D, Chang D, Thomason A, Yoshinaga SK (1996) Transformation of NIH 3T3 cells by HER3 or HER4 receptors requires the presence of HER1 or HER2. J Biol Chem 271:3884-3890. 